Discussion

Papers

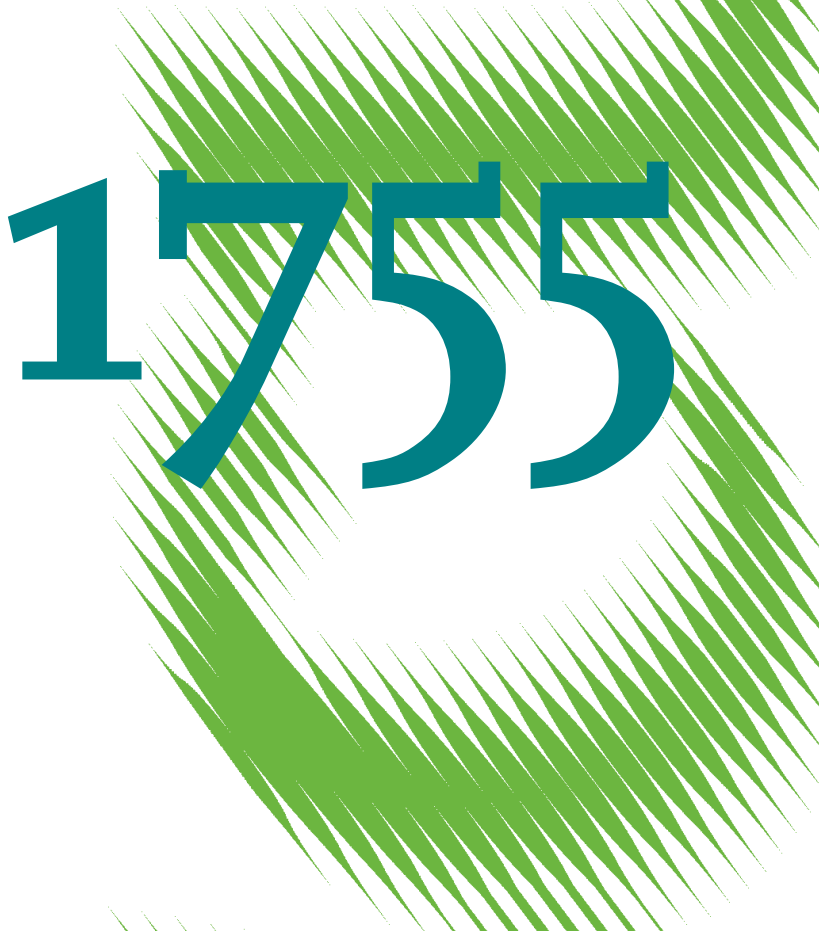

Monetary Policy and Inflation Dynamics in ASEAN Economies 
Opinions expressed in this paper are those of the author(s) and do not necessarily reflect views of the institute.

IMPRESSUM

(C) DIW Berlin, 2018

DIW Berlin

German Institute for Economic Research

Mohrenstr. 58

10117 Berlin

Tel. +49 (30) $89789-0$

Fax +49 (30) $89789-200$

http://www.diw.de

ISSN electronic edition 1619-4535

Papers can be downloaded free of charge from the DIW Berlin website:

http://www.diw.de/discussionpapers

Discussion Papers of DIW Berlin are indexed in RePEc and SSRN:

http://ideas.repec.org/s/diw/diwwpp.html

http://www.ssrn.com/link/DIW-Berlin-German-Inst-Econ-Res.html 


\title{
Monetary Policy and Inflation Dynamics in ASEAN Economies
}

\author{
Geraldine Dany-Knedlik ${ }^{1}$
}

\author{
Juan Angel Garcia²
}

July 2018

\begin{abstract}
This paper investigates the evolution of inflation dynamics in the five largest ASEAN countries between 1997 and 2017. To account for changes in the monetary policy frameworks since the Asian Financial Crisis (AFC), the analysis is based on country-specific Phillips Curves allowing for time-varying parameters. The paper finds evidence of a higher degree of forward-looking dynamics and a better anchoring of inflation expectations, consistent with the improvements in monetary policy frameworks in the region. In contrast, the quantitative impact of cyclical fluctuations and import prices has gradually diminished over time.
\end{abstract}

JEL Classification Numbers: C22, E31, E5

Keywords: Phillips curve, monetary policy, inflation expectations, ASEAN countries

\footnotetext{
${ }^{1}$ DIW Berlin, Department Macroeconomics and Financial Markets

2 International Monetary Fund, Asian Pacific Department

Acknowledgements: We thank Ana Corbacho, Giovanni Ganelli, Jaime Guajardo, Souvik Gupta, Minsuk Kim, Umang Rawat, Oliver Holtemöller, Gregor von Schweinitz, Jan-Christopher Scherer, Axel Lindner and Boreum Kwakfor very valuable comments on earlier drafts. We are also indebted to Aubrey Poon for great research work on the trend inflation estimates used in this paper. Remaining errors are our responsibility.
} 


\section{Contents}

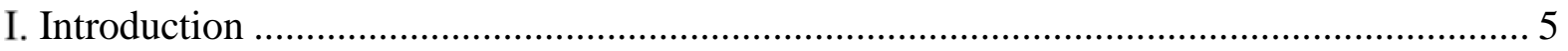

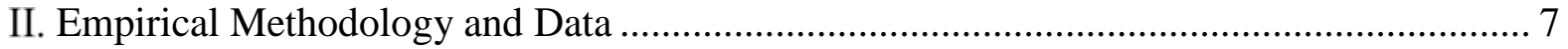

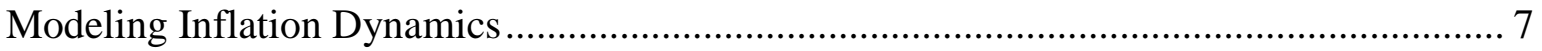

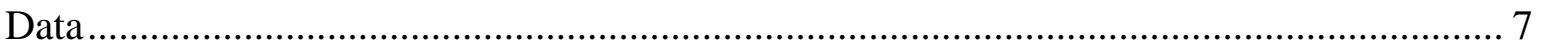

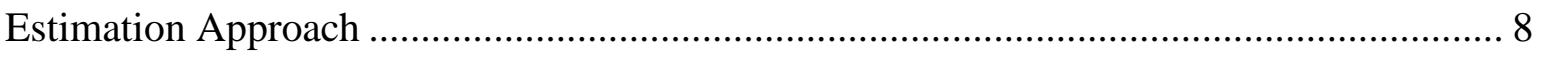

III. What drives inflation dynamics in ASEAN-5 countries? ........................................... 8

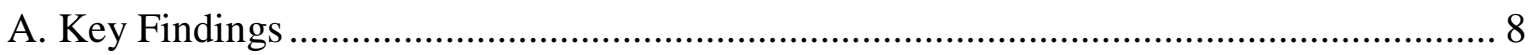

The Role of Forward-Looking Dynamics.............................................................. 10

Inflation Dynamics and Cyclical Fluctuations....................................................... 15

Inflation Dynamics, Non-oil-import and Oil Price Inflation ........................................ 16

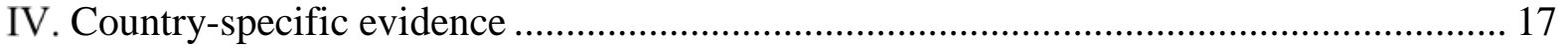

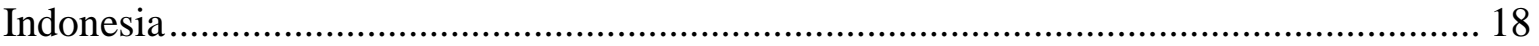

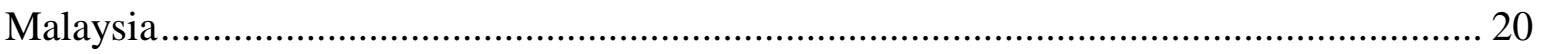

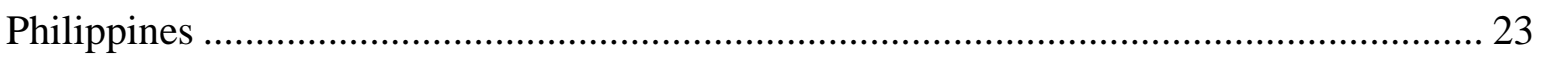

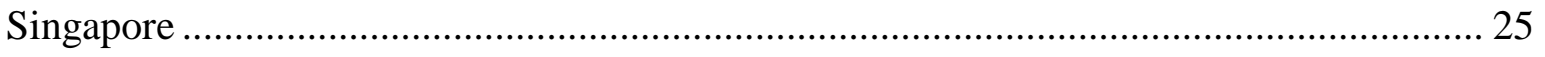

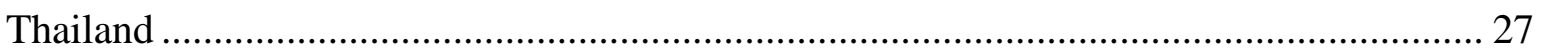

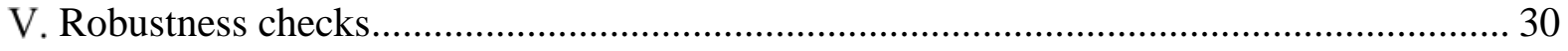

A. Different Measures of Macroeconomic Indicators …................................................ 30

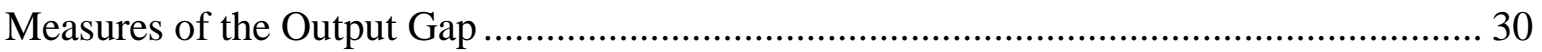

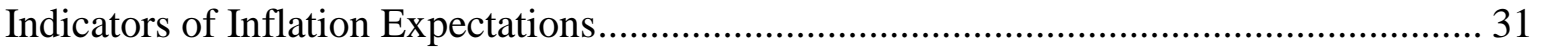

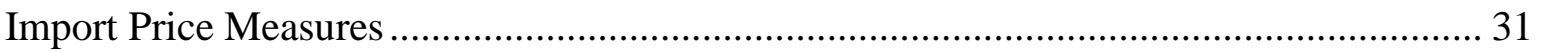

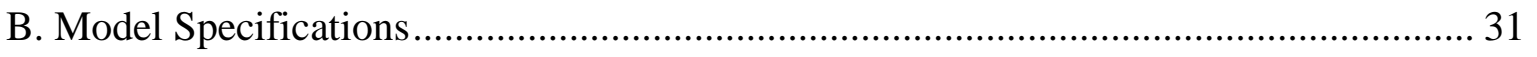

Impact of Time-varying Parameters .................................................................... 32

Coefficients of Non-Oil-Import Price and Oil Price Inflation ........................................ 33

Models including oil price inflation and exchange rate.............................................. 33 


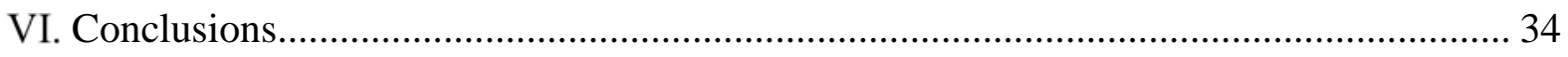

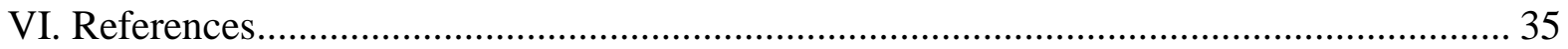

\section{Figures}

Figure 1: Relative Median Contribution of Inflation Drivers in ASEAN-5 countries .............. 9

Figure 2: Long-term Inflation Expectations (Trend Inflation Estimates)................................ 11

Figure 3: Consensus Long-term Inflation Expectations ........................................................... 11

Figure 4: ASEAN-5 CBs: Dincer-Eichengreen CB transparency index .................................. 14

Figure 5: Correlation Between Forward-looking Dynamics and DE transparency:

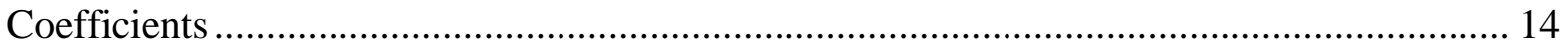

Figure 6: Correlation Between Forward-looking Dynamics and DE transparency:

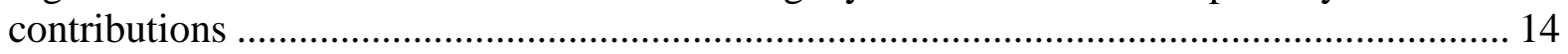

Figure 7: Median Contribution of Output Gap in ASEAN-5 countries................................... 16

Figure 8: Phillips Curve Slope Estimates 16

Figure 9: Median Contribution of Import Inflation in ASEAN-5 countries 17

Figure 10: Main Inflation Components: Indonesia ................................................................ 18

Figure 11: Time-varying Coefficient Estimates: Indonesia...................................................... 19

Figure 12: Main Inflation Components: Malaysia................................................................... 21

Figure 14: Main Inflation Components: Philippines .............................................................. 21

Figure 15: Time-varying Coefficient Estimates: Philippines ................................................... 24

Figure 16: Main Inflation Components: Singapore …………………………………........... 24

Figure 17: Time-varying Coefficient Estimates: Singapore ...................................................... 26

Figure 18: Main Inflation Components: Thailand ................................................................. 28

Figure 20: Contributions resulting from time-varying parameters:Thailand........................... 28

\section{Tables}

Table 1: Monetary policy Frameworks and Transparency in ASEAN-5 Countries 


\section{INTRODUCTION}

Inflation dynamics in the five founding members (Indonesia, Malaysia, the Philippines, Singapore, and Thailand) of the Association of Southeast Asian Nations (ASEAN) have experienced substantial changes since 1998 (see IMF, 2018a). In line with the experience of many emerging economies adopting inflation targeting regimes, headline inflation and inflation volatility in the ASEAN-5 economies have declined significantly since the early 2000s. However, inflation challenges have not disappeared. Asian economies weathered well disinflationary pressures in the aftermath of Global Financial Crisis (GFC), but the decline in oil prices since 2014 has proven more challenging. From a monetary policy perspective, whether this disinflation stems from high sensitivity of inflation to oil price changes or a weakening of forward-looking dynamics and the anchoring of inflation expectations yields very distinct implications.

Against this background, the aim of this paper is twofold. First, it provides evidence on how inflation dynamics have evolved in ASEAN-5 economies since 1988. Second, it explores the extent to which changes in inflation dynamics can be attributed to the improvement of monetary policy frameworks.

To get quantitative evidence on inflation dynamics in ASEAN-5 economies, we employ a hybrid New Keynesian Phillips Curve specification (e.g. Galí and Gertler, 1999) extended to an open-economy context ${ }^{3}$ and allowing for time variation in the parameters along the lines of Ball and Mazumder (2011) and Blanchard (2016), among others. More specifically, this paper documents the changes in the contribution of long-term expectations (i.e. forward-looking dynamics), economic slack, oil price inflation, and non-oil-import price inflation across ASEAN countries since 1996.

Using our novel evidence on the main inflation drivers in the region, we explore the link between monetary policy transparency and inflation dynamics. The five largest ASEAN countries may offer very interesting lessons of how the improvement of monetary policy frameworks can change inflation dynamics and the challenges that remain looking forward. Thus our results are useful for many other Emerging Economies that are involved in the improvement of their monetary policy regimes while facing the challenges of increased globalization.

Our main findings are as follows. The adoption of price stability as a major monetary policy objective, higher central bank transparency, and enhanced communication have improved the anchoring of inflation expectations and led to stronger forward-looking dynamics (or lower persistence) in inflation since 1998. In contrast, the quantitative impact of cyclical fluctuations has gradually diminished over time. Interestingly, we find evidence of a significant flattening of the Phillips Curve in ASEAN economies since the GFC. Since these economies were relatively less affected by the crisis than many other advanced economies, our findings suggest

\footnotetext{
${ }^{3}$ We abstract from theoretical derivations of the hybrid NKPC and do not include terms of trade in our Phillips curve specification. Instead we follow the specification of Blanchard (2016).
} 
the Phillips Curve flattening may be a global phenomenon (e.g. Ball and Mazumder, 2011, Blanchard et al, 2015), with potentially far reaching implications for monetary policy worldwide.

Our results support the fact that exchange rate liberalization, economic development, and technological progress have contributed to reducing the effect of non-oil and oil import inflation on headline inflation. However, strong disinflation and, in some cases, outright deflation in oil-importing economies (Singapore, Thailand) since 2014 indicate that supplyside shocks are not fully counterbalanced by the forward-looking component of the inflation process in ASEAN-5 yet.

This paper contributes to the growing interest on inflation analysis for the ASEAN countries (e.g. Direkudomsak, 2016, Guinigundo, 2016, Hendar, 2016, Khemangkorn et al., 2008, Meng, 2016, Singh, 2016). Nevertheless, the existing literature on inflation dynamics in the ASEAN region is limited, mainly focusing on country-specific analyses using different model specifications, data samples, and estimation techniques. We provide a common framework that allows for better international comparison not only among ASEAN countries but also as an example to many other emerging economies. Our analysis extends the findings that inflation targeting lowers inflation persistence (e.g. Benati, 2008, for advanced economies, Gerlach and Tillmann, 2012, for some Asian countries) as well as the positive correlation between central bank transparency and the anchoring of inflation expectations (e.g. Van der Cruijsen and Demertzis, 2007) to ASEAN economies. Our paper also provides additional quantitative evidence supporting the exhaustive reviews of the evolution of monetary policy frameworks in Asia and the ASEAN region (e.g. Morgan, 2013, IMF, 2016).

The remainder of the paper is organized as follows. Section II describes our benchmark model specification and the data used in our empirical work. Section III discusses our main findings for the region as a whole, focusing on the potential impact of enhanced monetary policy transparency and communication on inflation dynamics. In addition, we document a flattening of the Phillips Curve in the ASEAN-5 countries since the GFC. A detailed discussion of country-specific results is provided in Section IV. Section V discusses robustness checks regarding data and our benchmark Phillips Curve specification. Section VI finally concludes. 


\section{EMPIRICAL METHODOLOGY AND DATA}

\section{Modeling Inflation Dynamics}

A key goal of this paper is to unveil the main drivers of inflation dynamics in ASEAN-5 economies. Our empirical approach relies on the estimation of Phillips Curves at the country level. Our specification builds on the hybrid New Keynesian Phillips Curve (NKPC) specification of Fuhrer and Moore (1995) and Galí and Gertler (1999), among others. To allow for potential changes in the coefficients over time, either from the evolution of monetary policy regimes or reflecting changes in the global economic environment since the onset of the GFC, we allow for time-varying coefficients in our estimation, along the lines of IMF (2016), Blanchard (2016) and Dany-Knedlik and Holtemöller (2017), among others.

Formally, we estimate the following Phillips Curve as a benchmark specification:

$$
\pi_{t}=\beta_{t}^{1} \bar{\pi}_{t}+\left(1-\beta_{t}^{1}\right) \pi_{t-1}^{M A 4}+\beta_{t}^{2} \tilde{y}_{t-1}+\beta_{t}^{3} \pi_{t}^{I M}+\varepsilon_{t}
$$

where $\pi_{t}$ is headline consumer price index inflation, $\bar{\pi}_{t}$ denotes long-run inflation expectations, $\pi_{t-1}^{M A 4}$ is the moving average of inflation over the previous four quarters, $\tilde{y}_{t-1}$ is the economic slack measured as the output gap, $\pi_{t}^{I M}$ is inflation of imported goods and services and $\varepsilon_{t}$ is the measurement error and is assumed to be a Gaussian white noise process. In terms of economic interpretation, the coefficient $\beta_{t}^{1}$ measures how much inflation is driven by longterm expectations; that is, the forward-looking component of inflation in contrast to the influence of lagged inflation, which in turn is captured by $\left(1-\beta_{t}^{1}\right) . \beta_{t}^{2}$ measures the impact of cyclical economic activity on inflation, i.e. the slope of the Phillips Curve. Finally, the effect of import price inflation is captured by $\beta_{t}^{3}$.

\section{Data}

We use quarterly data from 1995Q1 until 2016Q4 for ASEAN-5 countries. Due to data limitations, the Indonesia and Malaysia samples start in 1998Q1. Our benchmark specification uses headline consumer price indexes and real GDP from the World Economic Outlook (WEO) database and import price indices from the HAVER database. Import price and headline CPI are included in the estimation as year-on-year inflation rates. The output gap is computed using the standard HP-filter. As our measure of long-term inflation expectations, our benchmark specification uses trend estimates from Garcia and Poon (2018, see section III.A for further details). For the computation of contributions (see Section III for details) and for further robustness checks (see section IV for details), we also use crude oil price and nominal exchange rates from the HAVER database, as well as long-run inflation expectations from Consensus Economics. 


\section{Estimation Approach}

We estimate the model using a standard Kalman filter with Gauss-Newton optimization with the Marquardt step method. Starting values for parameters and variances are taken from OLS regressions over a ten-year rolling window. We also introduce country-specific variance ratios across all state equations based on the signal to noise ratios from the rolling window estimation.

To sharpen the discussion, particularly over the 2014-16 disinflationary episode, we decompose the contribution of import price inflation into non-oil-import price inflation and oil price inflation using a regression analysis in line with $\operatorname{IMF}(2013,2016)$. As a robustness check, in Section IV we relax this assumption, directly estimating non-oil import and oil price inflation contributions.

\section{WHAT DRIVES INFLATION DYNAMICS IN ASEAN-5 COUNTRIES?}

We discuss our results in two steps. We first provide an overview of our key findings from a multi-country perspective, highlighting the main characteristics of inflation dynamics in the ASEAN-5 region. In a second stage, we elaborate in greater detail the country-specific findings, in particular over the disinflation period experienced in those countries between 2014-16.

\section{A. Key Findings}

To illustrate the contributions of the different inflation drivers across ASEAN-5 countries, we use the country-specific estimations and compute the relative median contribution of long-term expectations (i.e. forward-looking dynamics), economic slack, oil price inflation, and non-oilimport price inflation across countries over time (see Figure 1). The main insights are as follows.

We find that inflation expectations are the most important driver of inflation dynamics across ASEAN-5 countries, explaining an average of around $60 \%$ of median inflation in the region. Compared to the importance of expectations, the contributions of economic slack, non-oilimport, and oil price inflation are modest, explaining an average of only $9 \%, 12 \%$ and $7 \%$, respectively; which is broadly in line with the estimation residual (9\%).

ASEAN-5 inflation is increasingly forward-looking since the AFC, although the contributions of inflation expectations somewhat declined during the GFC and during the low inflation period of 2014-16. Forward-looking dynamics averaged 43\% between 1996 and 2001, increasing to around 66\% thereafter, declining temporarily over the GFC (57\%) and the disinflation period (61\%).

The contributions of economic slack to inflation have gradually become more limited over the sample as a whole, but showing some higher relevance in recessionary episodes. From 1995 
through 2007, economic slack explained around 7\% of headline inflation and, although it rose to $15 \%$ over the economic expansion between 2002 and 2007, that rise was temporary and thereafter declined to less than $5 \%$. However, higher contributions in recessionary periods point to some non-linearities in the transmission of supply shocks in the region, while the more muted impact of economic activity on inflation dynamics since the GFC is consistent with available evidence for advanced economies over the same time period (e.g. Watson, 2014, among others).

Figure 1: Relative Median Contributions to Inflation

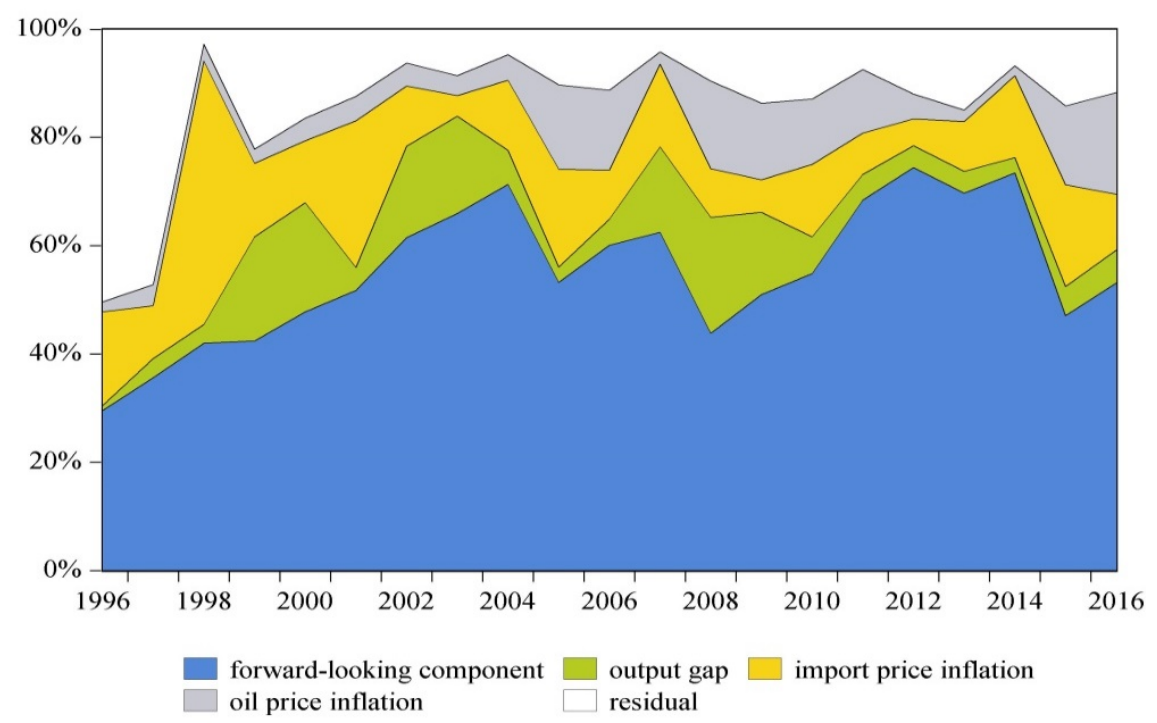

Note: We obtain the relative median contributions by estimating equation (1) for each country and simulating the contributions of the four inflation drivers as well as for the residual. We then take the median contribution of driver and of headline inflation rates at each point in time across countries. The relative median contribution is then the median contribution of a specific driver over the median headline inflation.

The quantitative importance of import price inflation for ASEAN-5 inflation dynamics have changed significantly since 1988. Non-oil import inflation and, to a less extent, oil price inflation were jointly the major drivers of inflation rates during the AFC (almost 27\%). Thereafter, however, their contributions declined (to around $8 \%$ and $5 \%$, respectively, for most of the sample). Only over the 2014-16 disinflationary episode did non-oil-import and oil price inflation contributions (15\% and $18 \%$ of median headline inflation, respectively) rebound. The removal of subsidies throughout the years and the potential improvements in the price discovery mechanism in the ASEAN-5 economies may have contributed to attenuate the impact of imported inflation on overall inflation.

Overall, the stylized facts above inflation dynamics discussed above are very much in line with the experience of many other advanced and emerging economies. Indeed, there is evidence that global inflation factors play an important role in inflation developments in most countries and that the ASEAN-5 economies are not immune to these influences (see IMF, 2018b). 


\section{The Role of Forward-Looking Dynamics}

The increase in the forward-looking component of inflation dynamics after the AFC is one of the key findings of our analysis. We argue that such a change is related to most ASEAN-5 countries enhancing their monetary policy frameworks and operational practices since the AFC. We provide additional supporting evidence for this conjuncture below. In terms of our empirical framework, the coefficient on forward-looking dynamics, $\beta_{t}^{1}$, and the level of (longterm) trend inflation, $\bar{\pi}_{t}$, play a crucial role in providing stable inflation rates and macroeconomic stability. Thus, these are crucial for monetary policy.

Guiding long-term inflation expectations are a crucial element of modern monetary policy making. The consistency of private sector's inflation expectations at medium-to-long horizons with the central bank's target provides a direct assessment of the credibility of monetary policy. Moreover, in an environment of very low inflation, stable long-term inflation expectations are essential to bring inflation back to target.

Surveys of inflation expectations and expectations extracted from financial instruments are among the standard indicators monitored by many central banks. ${ }^{4}$ In addition, since the GFC, the estimation of long-term inflation trends using econometric models is increasingly common by major central banks. The rationale behind this research effort is twofold. First, given the forward-looking orientation of modern monetary policymaking, policy decisions should be based on reliable indicators of long-term inflation expectations. While survey and financial indicators provide useful information, both have important shortcomings that may render them less reliable in an environment characterized by persistently low inflation. Second, discrepancies between both types of indicators require a regular assessment of their information content and the estimation of trend inflation measures can be instrumental in that regard.

Among the ASEAN-5 countries, break-even inflation rates (BEIRs) are only available for Thailand and, therefore, are not an alternative variable of choice as a measure of $\bar{\pi}_{t}$ in our econometric exercise. To account for the aforementioned shortcomings of survey-based expectations, we employ trend inflation estimates from Garcia and Poon (2018). ${ }^{5}$ Their framework uses survey-based expectations as an additional source of information to estimate trend inflation-the optimal conditional long-term inflation forecasts-while allowing for potential deviations of survey-based expectations from the estimated level of trend inflation.

\footnotetext{
${ }^{4}$ Surveys are a traditional source of information about long-term expectations, as they are available for many countries over several decades, reporting information several times a year. With the issuance of inflation-linked bonds in many advanced but also emerging economies, the so-called "break-even inflation rate" (BEIR) - the yield spread between comparable conventional bonds and ILBs - is also a crucial indicator of inflation expectations. BEIRs often provide more timely information on investors' inflation expectations than do survey-based expectations. Yet, in addition to the expected inflation, BEIRs may incorporate other factors, notably inflation risk and liquidity risk premium, and should better be interpreted as the overall inflation compensation requested by investors to hold nominal assets, rather than a pure measure of expected inflation.

${ }^{5}$ Based on the methodology introduced by Chan et. al (2018).
} 
Figure 2: Long-term Inflation Expectations (trend inflation estimates, percent)

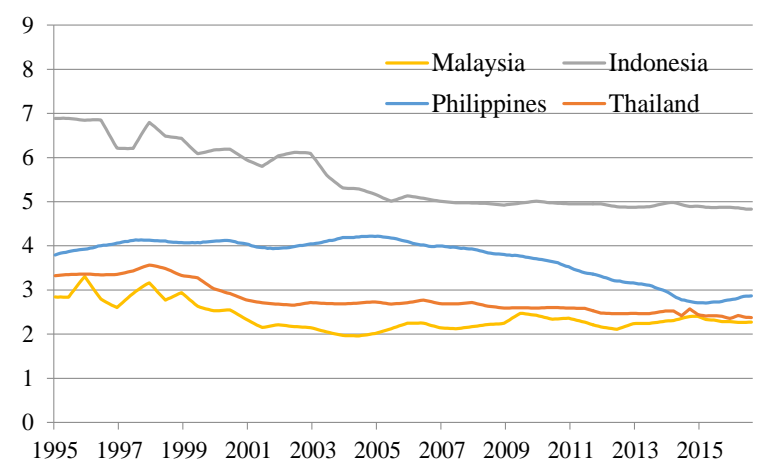

Figure 3: Consensus Long-run Inflation Expectations (percent)

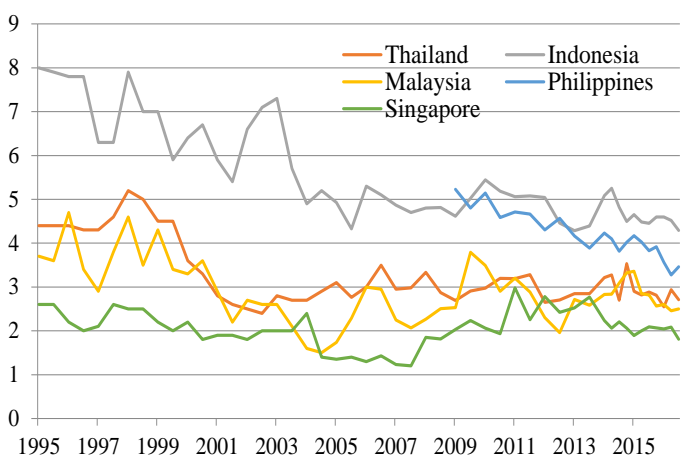

Figures 2 and 3 depict the long-term trend inflation estimates included in our benchmark estimation compared to the Consensus Economics long-term (6-10 years ahead) expectations. Survey expectations are substantially more volatile compared to trend inflation estimates. For Malaysia, Indonesia, and Thailand trend estimates lie below the survey expectations throughout the sample. Within the framework of Garcia and Poon (2018) and Chan et al. (2018), this points toward a systematic deviation of actual trend expectations that can be explained by informational rigidities (see Coibion and Gorodnichenko, 2015, and Mertens and Nason, 2015).

The role of monetary policy to foster forward-looking dynamics is twofold. Aligning private sector's inflation expectations at medium-to-long horizons to the central bank's target is necessary, but not sufficient, for stabilizing inflation dynamics. Additionally, long-run inflation expectations should exert a substantial influence on inflation dynamics, e.g. actual inflation should have an important degree of forward-looking dynamics, as opposed to being driven by past inflation only. In other words, the private sector's (long-term) inflation expectations should be aligned to the central bank's inflation target-the public should regard the inflation target as a highly likely outcome for actual inflation in the future-and economic agents should also incorporate the inflation target into their pricing decisions.

In our hybrid Phillips Curve specification (1), the sum of the degree of forward and of backward looking dynamics is set to unity. Thereby, $\beta_{t}^{1}$ determines the importance of inflation long-term expectations and $\left(1-\beta_{t}^{1}\right)$ represents the importance of past inflation or inflation persistence. Gali and Gertler (1999) provide the theoretical foundation for this specification. They augment the new Keynesian Phillips Curve by assuming two groups of price setters; one that sets prices according to the purely forward-looking NKPC and the other that is adjusting prices according to price indexation, whereby prices are set equal to the average of the most recent round of price adjustments, i.e. to past inflation (Calvo, 1983). 


\section{Forward-looking Inflation Dynamics and Central Bank Transparency}

Central bank transparency is essential for managing inflation expectations and its impact on inflation dynamics. As pointed out by Blinder et al. (2008), central bank transparency matters because both the underlying structure of the economy and the monetary policy framework may change over time; further, should such changes occur, the central bank should clearly communicate them to the public to enhance monetary policy effectiveness. Transparency should be fundamental whenever information on the macroeconomic situation is asymmetrically distributed between the central bank and the public, as well as when expectations are not completely rational. Against this general background, effective communication of the central bank's objectives and its strategy, its decisions, and the rationale behind them, as well as information about the outlook for inflation, real economic activity and the economy in general, are crucial elements of a transparent monetary policy. In our empirical model, a transparent central bank should be capable of aligning public long-run trend expectations $\left(\bar{\pi}_{t}\right)$ to the central bank's inflation target, and achieve a certain degree of forwardlooking behavior in price setting.

Since 1998, central bank transparency increased significantly in the ASEAN-5 countries. Before the AFC, pegged exchange rate regimes dominated the monetary policy environment in the ASEAN-5 region. Excessive borrowing and currency mismatch by corporates and banks led to severe exchange rate pressures and depreciations when capital flows reversed. Since the AFC, in order to strengthen monetary policy independence and to gain more open capital accounts, all of the ASEAN-5 increased their exchange rate flexibility. In addition, ASEAN-5 central banks made significant improvements in their operating frameworks and policy objectives, as well as in communication efforts as a response to challenges coming from the global economic environment (see e.g. Morgan, 2013, IMF, 2018).

Table 1 summarizes the status of the monetary policy frameworks and communication practices in ASEAN-5 countries as of fall 2018. Low and stable inflation is included in monetary policy objectives in all ASEAN-5 countries with Indonesia, the Philippines, and Thailand adopting an explicit (but in some cases flexible) inflation targeting regime. Further, all 5 countries communicate policy, including a statement of a primary policy objective, the medium-term inflation target, as well as the publication and explanation of monetary policy decisions. The heterogeneities across availability and timing of the publications of minutes, as well as inflation rates, point to further potential for improving central bank transparency and communication across the ASEAN-5 region.

Figure 4 depicts a quantitative measure of central bank transparency-the Dincer and Eichengreen (2014) central bank transparency index (DE index) - for ASEAN-5 countries. For reference purposes, a benchmark average index of the top 5 scoring countries (Czech Republic, Israel, New Zealand, Hungary and Sweden) is also depicted. Starting with low scores between 2 and 4 index points in 1998, the index illustrates that ASEAN-5 countries have

gradually, but steadily, improved central bank transparency: Indonesia, Philippines and Thailand to scoring between 9 and 10 index points in 2014, with Malaysia and Singapore scoring 6 and 5, respectively. Compared to the top 5 performers, however, there is generally still room for further improvements of central bank transparency in ASEAN-5 countries. 
Table 1: Monetary Policy Frameworks and Transparency in ASEAN-5 Countries

\begin{tabular}{|c|c|c|c|c|c|}
\hline & Indonesia & Malaysia & Philippines & Singapore & Thailand \\
\hline $\begin{array}{l}\text { Central bank } \\
\text { mandate }\end{array}$ & $\begin{array}{l}\text { Achieve and } \\
\text { maintain a stable } \\
\text { value of rupiah }\end{array}$ & $\begin{array}{l}\text { Promote monetary } \\
\text { and financial } \\
\text { stability } \\
\text { conductive to } \\
\text { sustainable } \\
\text { growth of } \\
\text { Malaysian } \\
\text { economy }\end{array}$ & $\begin{array}{l}\text { Promote and } \\
\text { maintain price } \\
\text { stability provide } \\
\text { proactive } \\
\text { leadership in } \\
\text { bringing about a } \\
\text { strong financial } \\
\text { system, } \\
\text { conductive to a } \\
\text { sustainable } \\
\text { growth of the } \\
\text { economy }\end{array}$ & $\begin{array}{l}\text { Maintain price } \\
\text { stability foster a } \\
\text { sound and } \\
\text { reputable } \\
\text { financial stability } \\
\text { ensure prudent } \\
\text { and effective } \\
\text { management of } \\
\text { foreign reserves } \\
\text { and grow } \\
\text { Singapore's as } \\
\text { international } \\
\text { competitive } \\
\text { financial center }\end{array}$ & $\begin{array}{l}\text { Maintain } \\
\text { monetary stability } \\
\text { and payment } \\
\text { systems }\end{array}$ \\
\hline $\begin{array}{l}\text { Primary } \\
\text { monetary policy } \\
\text { objective }\end{array}$ & $\begin{array}{l}\text { Stable price of } \\
\text { goods and } \\
\text { services and } \\
\text { stable exchange } \\
\text { rate }\end{array}$ & $\begin{array}{l}\text { Price stability } \\
\text { with sustainable } \\
\text { growth }\end{array}$ & Price stability & Price stability & Price stability \\
\hline $\begin{array}{l}\text { Stated monetary } \\
\text { policy framework }\end{array}$ & $\begin{array}{l}\text { Inflation } \\
\text { targeting } \\
(2005)\end{array}$ & $\begin{array}{l}\text { Flexible inflation } \\
\text { targeting without } \\
\text { explicit anchor }\end{array}$ & $\begin{array}{l}\text { Inflation } \\
\text { targeting } \\
(2002)\end{array}$ & $\begin{array}{l}\text { Implicit inflation } \\
\text { targeting }\end{array}$ & $\begin{array}{l}\text { Flexible inflation } \\
\text { targeting } \\
(2000)\end{array}$ \\
\hline $\begin{array}{l}\text { Medium term } \\
\text { inflation target }\end{array}$ & $\begin{array}{l}3,5 \% \pm 1 \% \\
\text { (approved target } \\
\text { for 2018)) }\end{array}$ & $\begin{array}{l}\text { No explicit target } \\
\text { (about 3\% over } \\
\text { long-term) }\end{array}$ & $\begin{array}{l}3 \% \pm 1 \% \\
\text { (approved } \\
\text { target for 2015- } \\
2018 \text { ) }\end{array}$ & $\begin{array}{l}\text { Comfort level of } \\
\text { about } 2 \%\end{array}$ & $\begin{array}{l}2.5 \% \pm 1.5 \% \\
\text { (approved target } \\
\text { for 2018) }\end{array}$ \\
\hline \multicolumn{6}{|c|}{ Report on macroeconomic outlook } \\
\hline Inflation report & Monthly & No & Quarterly & Semi-annually* & Quarterly \\
\hline \multicolumn{6}{|c|}{ Decision and rational } \\
\hline $\begin{array}{l}\text { Monetary policy } \\
\text { stance }\end{array}$ & $\begin{array}{l}\text { Yes, on the day } \\
\text { of decision }\end{array}$ & $\begin{array}{l}\text { Yes, on the day of } \\
\text { decision }\end{array}$ & $\begin{array}{l}\text { Yes, on the day } \\
\text { of decision }\end{array}$ & $\begin{array}{l}\text { Yes, on the day } \\
\text { of decision }\end{array}$ & $\begin{array}{l}\text { Yes, on the day } \\
\text { of decision }\end{array}$ \\
\hline $\begin{array}{l}\text { Minutes policy } \\
\text { meetings }\end{array}$ & Yes & No & $\begin{array}{l}\text { Yes, one month } \\
\text { after the } \\
\text { meeting }\end{array}$ & No & $\begin{array}{l}\text { Yes, two weeks } \\
\text { after the meeting }\end{array}$ \\
\hline $\begin{array}{l}\text { Explanation of } \\
\text { decision making } \\
\text { process }\end{array}$ & Yes & Yes & $\begin{array}{l}\text { Yes (also letter } \\
\text { to the President } \\
\text { if target is } \\
\text { missed) }\end{array}$ & Yes & $\begin{array}{l}\text { Yes (also letter to } \\
\text { Minister of } \\
\text { Finance if target } \\
\text { is missed) }\end{array}$ \\
\hline
\end{tabular}

Supporting evidence on the link between central bank transparency and forward-looking dynamics in inflation are shown in Figures 5 and 6. Both the of time-varying estimates of the forward-looking coefficient, $\beta_{t}^{1}$, and the overall contribution of long-term expectations to inflation, $\beta_{t}^{1} \bar{\pi}_{t}$, are positively correlated with the respective DE transparency score for each country. Our results therefore support the view that the greater transparency in the ASEAN-5 central banks can be associated with a higher degree of forward-looking dynamics in these countries. 
Figure 4: ASEAN-5 CBs: Dincer-Eichengreen Central Bank transparency index

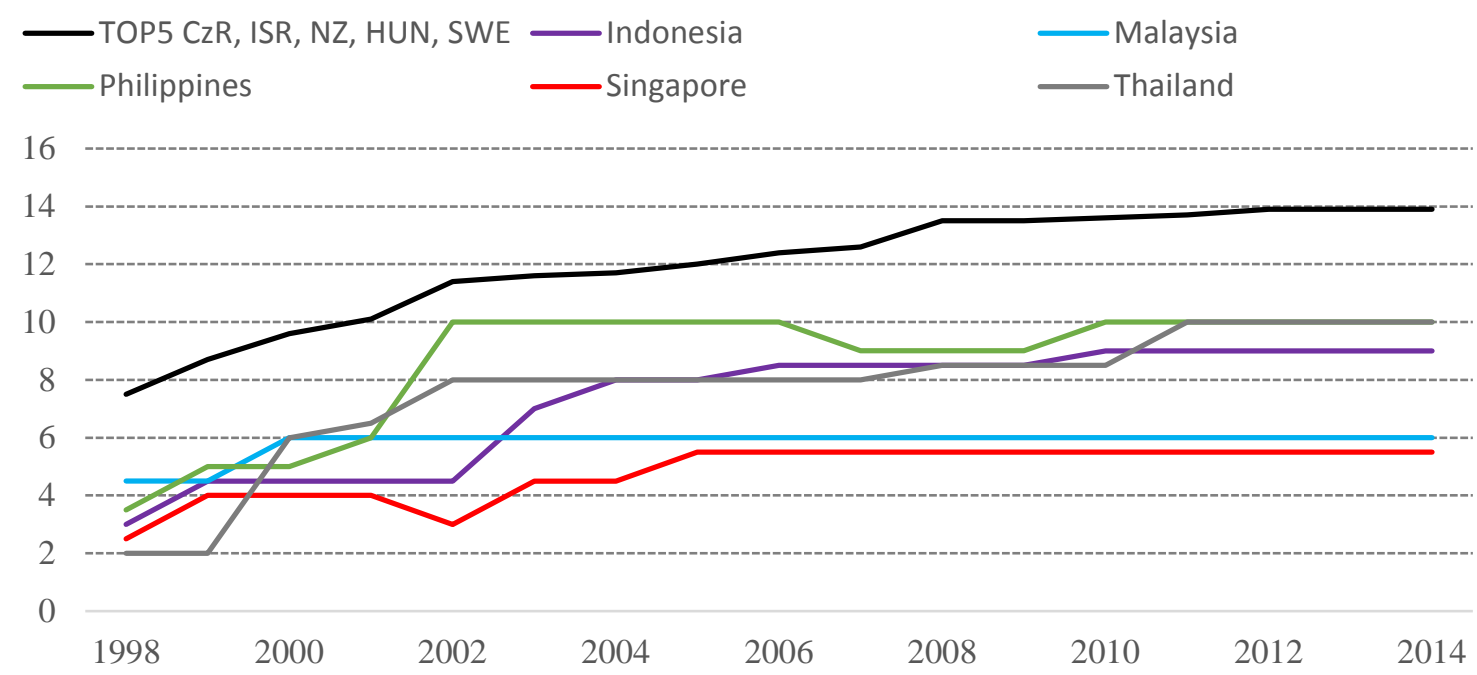

Note: Based on Dincer and Eichengreen (2014). Maximum score of 15 based on 5 dimensions of CB transparency including about policy objectives (explicit objectives, quantification, instrument independence), economic information used for monetary policy decisions (data, model and central bank forecasts), decision making process (policy strategy, prompt account of deliberations, voting information ), disclosure of policy decisions (prompt announcement, explanations, forward guidance), and policy implementation (evaluation with respect to targets, shocks impairing achieving goals, explain decision to achieve policy objectives). As reference, the scoring of the ASEAN-5 countries is compared to that of the top five countries in the DincerEichengreen sample (Czech Republic, Israel, New Zealand, Hungary and Sweden).

Figure 5: Degree of Forward-Looking Dynamics and Dincer-Eichengreen Transparency Index: estimated coefficients

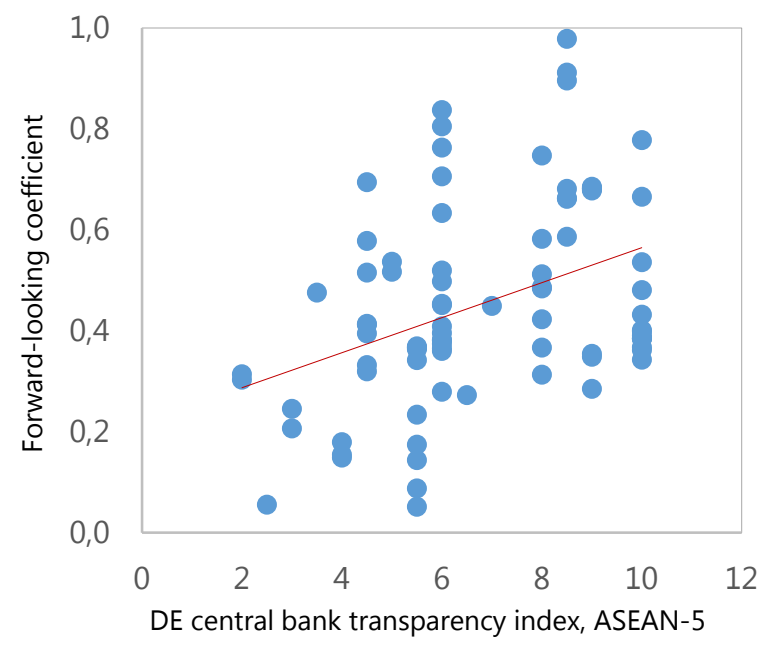

Figure 6: Degree of Forward-Looking Dynamics and Dincer-Eichengreen Transparency Index: estimated contributions

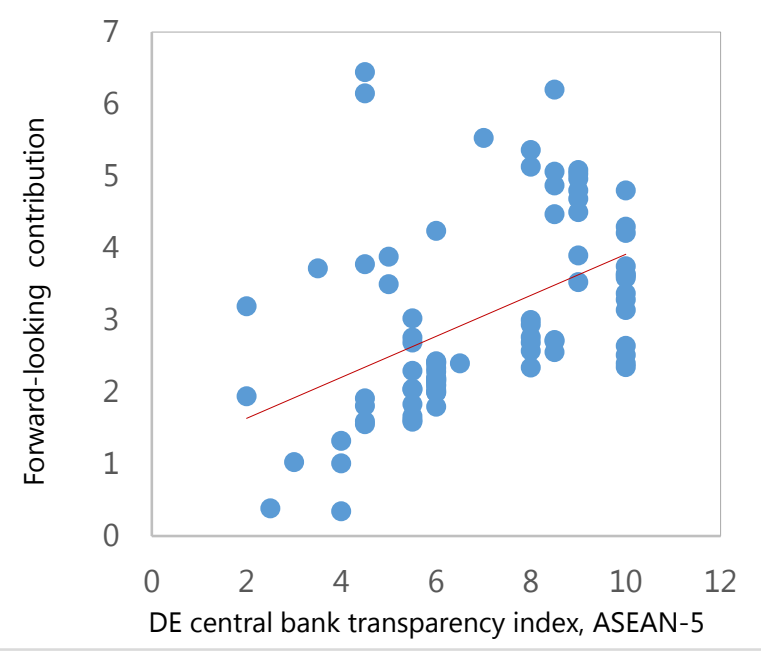




\section{Inflation Dynamics and Cyclical Fluctuations}

Since the postulation of a relationship between economic slack (unemployment or overall economic activity) and inflation, the slope of the Phillips Curve is a key parameter of interest (e.g. Blanchard et al., 2015). Thus, in the case of ASEAN-5 countries, it is important to discuss how strong the impact of the cyclical economic position is for inflation dynamics in the region.

The contribution of economic slack to overall inflation has fluctuated significantly since 1996 (see Figure 7). It was quantitatively more important prior to the GFC, but thereafter movements in economic slack have played a very limited role in the inflation process. The higher importance of economic slack in the first half of the 2000s is related to the structural transitions of the ASEAN-5 economies induced by exchange rate liberalization, enhanced economic policy, and intrinsic economic transitions; all part of the post AFC adjustment process.

The ASEAN-5 countries have experienced a flattening of the Phillips curve. Although in some cases that flattening may imply a decline from average, historical levels (e.g. Indonesia). While, for other countries with very high levels pre-2008, the bulk of the decline took place by early 2010s, but was followed by a stabilization at a lower level thereafter (see Figure 8). Such a flattening of the Phillips Curve is more in line with available evidence from advanced economies that were more severely affected by the GFC (e.g. Blanchard, 2016, IMF, 2013, 2016), despite the fact that ASEAN-5 economies were relatively less affected by the financial turbulences. However, it is not a phenomenon experienced by other advanced Asian economies. For example, South Korea has, in contrast, experienced a mild but nonetheless steepening of the Phillips Curve since 2010. Yet, such a steepening has compensated an earlier flattening that took place over the 2000s, but particularly in the second part of that decade. This evidence suggests that the ASEAN-5 economies may be experiencing a flattening of the Phillips Curve somewhat later than other advanced economies.

The flattening of the Phillips Curve in ASEAN-5 economies, we unveil here, has important implications for monetary policy and the understanding of inflation dynamics. For example, it helps explain the relatively low inflation experienced across ASEAN-5 economies in 2017 despite the growth momentum in all the countries in the region. Although the reasons why such a flattening of the Phillips Curve may be taking place are beyond the scope of this paper, ${ }^{6}$ it deserves close monitoring.

\footnotetext{
${ }^{6}$ The declining sensitivity of median inflation in ASEAN-5 to the output gap could also be linked to the behavior of potential output during period of declining inflation. For example, with a possible strengthening of potential output in ASEAN-5 since the GFC (Anand et al., 2014), fiscal and monetary policy may not have to react strongly and this may affect the estimates of the PC slope.
} 
Figure 7: Median Contribution of Output Gap to Inflation in ASEAN-5 countries

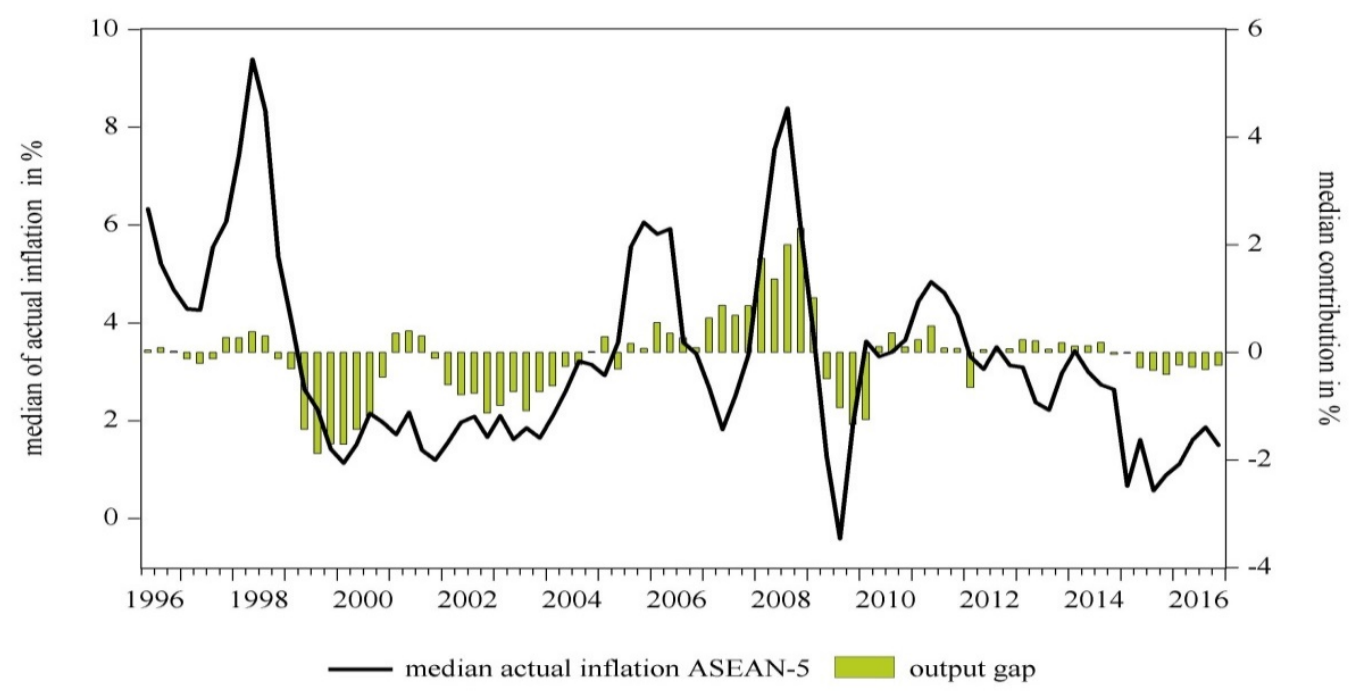

Figure 8: Phillips Curve Slope in the ASEAN-5 and South Korea

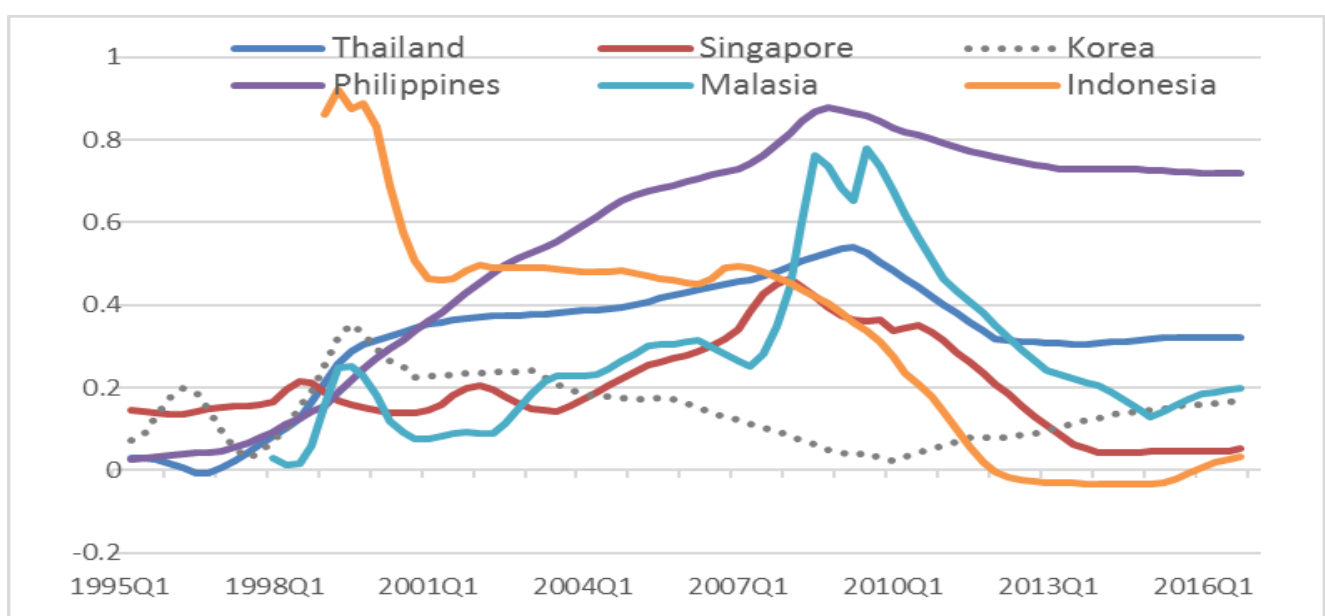

Note: $\beta_{t}^{2}$ parameter in equation $\pi_{t}=\beta_{t}^{1} \bar{\pi}_{t}+\left(1-\beta_{t}^{1}\right) \pi_{t-1}^{M A 4}+\beta_{t}^{2} \tilde{y}_{t-1}+\beta_{t}^{3} \pi_{t}^{I M}+\varepsilon_{t}$ estimated at country level

\section{Inflation Dynamics, Non-oil-import and Oil Price Inflation}

The sharp fall in oil prices is a recurrent explanation for the low inflation rates since 2014. This raises the question of whether oil price inflation generally a strong impact on headline inflation, or whether the magnitude of the oil price decline since 2014 was an unusual episode of oil prices driving inflation developments. When looking at the relation between headline inflation and oil price inflation for the ASEAN-5 group as a whole, it is important to bear in mind that Malaysia and Indonesia are oil producing countries, while Thailand, Philippines and Singapore are oil importers. 
Figure 9: Median Contribution of Import Price Inflation in ASEAN-5 Countries

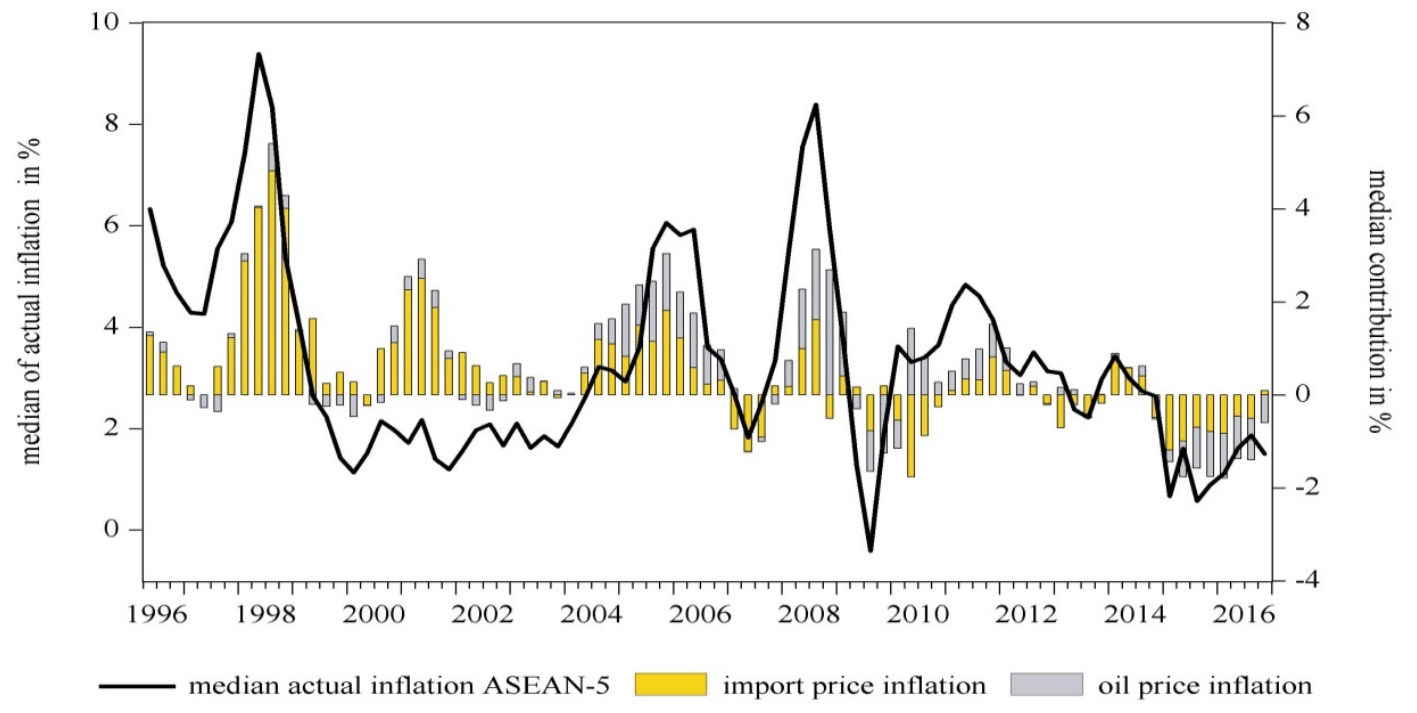

As shown in Figure 9, the combined contributions of non-oil-import and oil price inflation declined substantially following the AFC. Yet, while the quantitative importance of non-oil import inflation has diminished significantly since the early 2000s, that of oil price inflation rose after the AFC. Oil price contributions lie between 0.30 percentage points and -0.49 percentage points from 1996-2001 and the contributions range increases to (1.41 -0.17 percentage points) between 2002 and 2008. In the period of disinflation between 2014 and 2016, oil price inflation drove down median inflation by -0.46 percentage points in 2015 and 0.59 percentage points in 2016, suggesting that the contributions were substantial, but not out of range with other historical episodes.

In sum, our analysis suggests that since 1998 long-run inflation expectations have become the most important driver of ASEAN-5 inflation. This development is highly correlated to the evolution and enhancement of monetary policy frameworks and central bank communication in those countries. Other traditional drivers, for example the output gap movements, have a more limited impact on headline inflation in normal conditions, but are much stronger during crisis periods. The contribution of import inflation is also increasingly limited over time, although has been rather stable since the early 2000s. The next section looks at the individual country experiences in greater detail.

\section{COUNTRY-SPECIFIC EVIDENCE}

This section discusses our estimation results at the country level. The purpose is twofold. First, we report our estimation results in greater detail, including the evolution of time-varying parameters and the uncertainty surrounding the estimates, as well as the implied contributions of drivers to headline inflation for each of the countries. Second, we illustrate how the individual country experiences relate to the general patterns discussed in the previous section. 


\section{Indonesia}

Indonesian inflation rate declined from an average of 8.5\% before the GFC to around 5\% after the GFC (see Figure 10). Yet, toward the end of our sample, disinflationary pressures have been limited, possibly reflecting a less direct impact of low commodity prices due to the fuel and electricity subsidies, although reduced since 2015, still in place.

The main drivers of Indonesian inflation process have changed over time to become less dependent on real economic activity and import inflation. In the early 2000s, economic slack and import inflation accounted for half of inflation developments: for example, in 2002 Indonesian inflation rate was about $12 \%$. of which 6.3 percentage points was explained by economic activity and import inflation (3.5 percentage points by the output gap, 2.1 percentage points by non-oil-import prices, and 0.8 percentage points by oil price inflation), with only 3.6 percentage points determined by expectations of future inflation. In contrast, in 2015 inflation expectations explained 4.9 percentage points of the $6.4 \%$ headline inflation rate, while economic slack accounted for 0.05 percentage points, non-oil-import inflation and oil price inflation contribute 0.8 percentage points and -0.5 percentage points, respectively.

Figure 10: Main Inflation Components: Indonesia

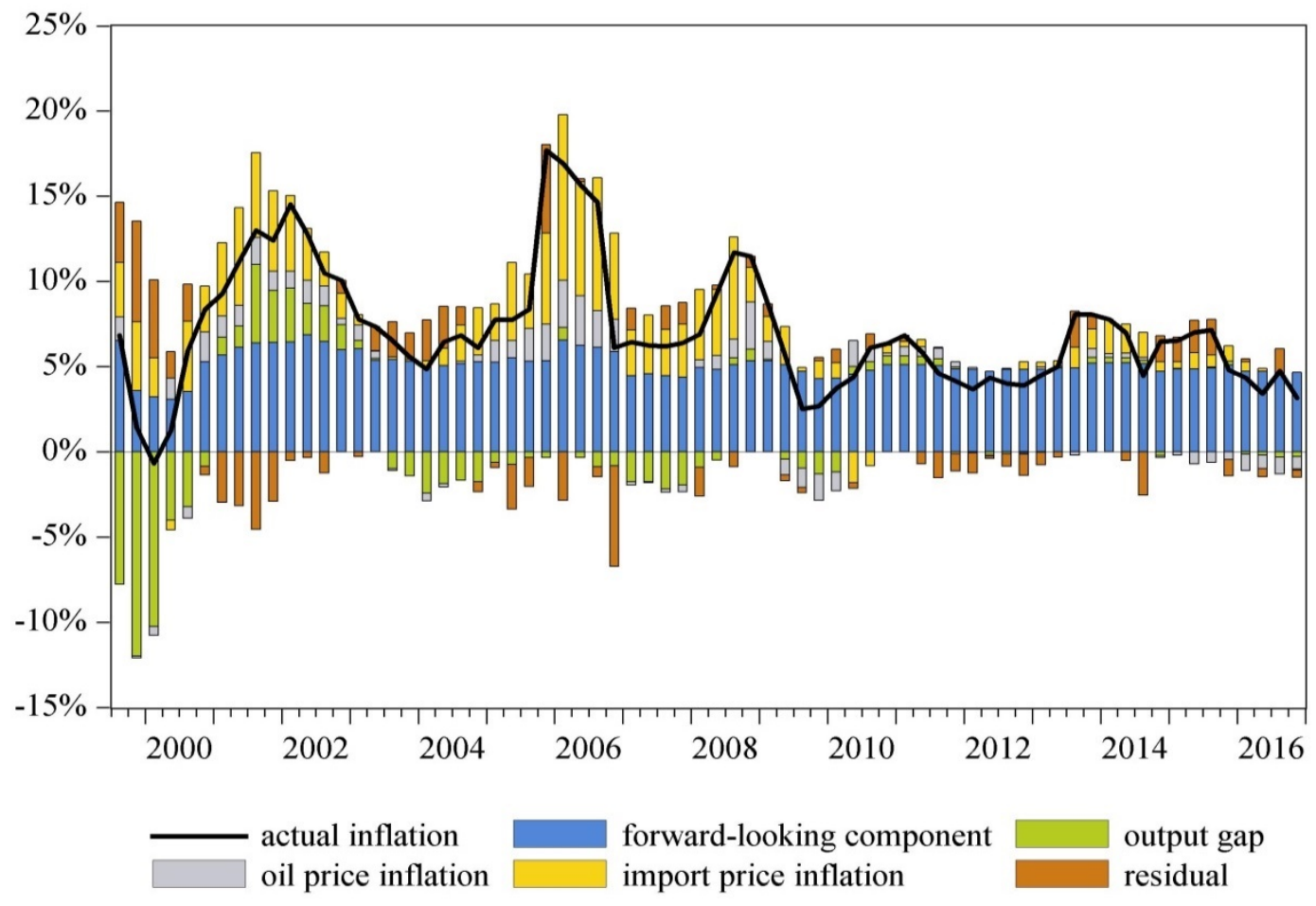


Figure 11: Time-varying Coefficient Estimates: Indonesia

(a) Trend expectation

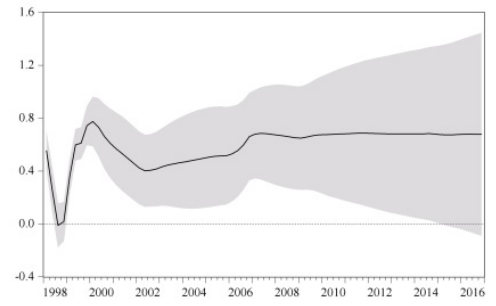

(b) Economic slack

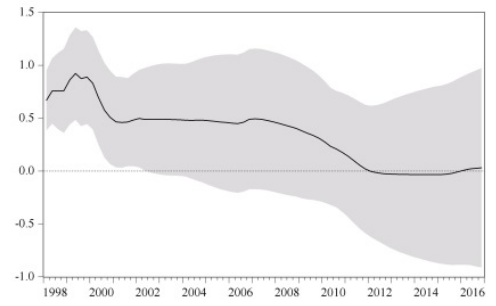

(c) Import inflation

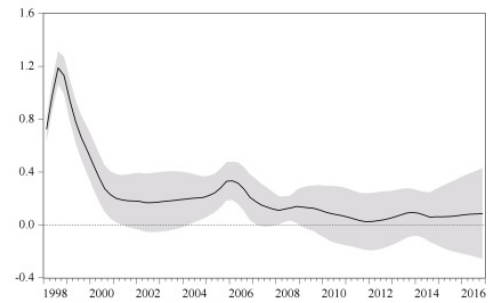

Improvements in the monetary policy framework coincide with the partially strengthened forward-looking dynamics of Indonesian headline inflation. Contributions of trend inflation expectations in Indonesia rise sharply in the first half of the 2000, stabilizing thereafter. In particular, the contribution of forward-looking dynamics increased by 74\% from 2001 (2.67 percentage points) to 2005 (4.7 percentage points) and continue to narrowly fluctuate around 4.7 percentage points since then. The reason for the increase is twofold. First, the coefficient of the forward-looking component (see Figure 11 panel a) rose from 0.32 in 2001 to 0.73 in 2007, stabilizing at around 0.7. Second, the Indonesian trend inflation estimates (see Figure 2) have fallen from 7.9\% in 2001 to 5\% from 2007 onwards.

The rise in forward-looking dynamics between 2002 and 2007 seemed to be related to the continuous improvement of the Bank Indonesia's (BI) monetary policy framework and communication strategy over that period. ${ }^{7}$ In particular, the Central Bank Act of 2004 outlined a clear mechanism for accountability and transparency of monetary policy, including the announcement of the inflation target and a monetary policy plan at the start of each year, the provision of a quarterly report to parliament on the conduct of monetary policy, the Monetary Policy Report, as well as the publication of decisions of Monetary Board meetings, the economic forecasting models, and a monetary policy outlook. Moreover, in early 2005 the BI began to use interest rates as its main policy instrument due to difficulties of controlling base money. ${ }^{8}$

Since the GFC, Indonesia's headline inflation is stable at low levels around 5\%. This stabilization can be related to improvements in monetary policy framework and communication together with a declining importance of import prices, including oil and non-

\footnotetext{
${ }^{7}$ In 2000, BI adopted an explicit inflation targeting framework to achieve and price stability, i.e. low and stable inflation, and stable exchange rates. Initially, base money was used as an operational target to achieve inflation targets defined in terms of core CPI inflation rates. As core inflation proved to be a more difficult concept to communicate to the public, the Central Bank Act No 3/2004 induced the government to set annual and medium-term inflation targets based on headline CPI inflation rates, following the BI's recommendations.

${ }^{8}$ Following the central bank reforms in 2004, inflation dynamics became somewhat more forward-looking. However, inflation volatility remained at high levels due to ad hoc adjustments of administered prices in 2005 and 2008, which led to actual CPI inflation higher than short-term targets. This created uncertainty over inflation expectations and affected monetary policy credibility as BI's communication mainly focused on short-term rather than medium-term inflation targets (IMF, 2010, Box 3). In mid-2010, BI re-evaluated its monetary policy framework including the adoption of a policy mix of monetary and macroprudential policies (IMF 2012). BI's communication has improved, focusing more on the medium-term inflation target and de-emphasizing other policy objectives s, like output and credit growth.
} 
oil. Further improvements in forward-looking monetary policy communication and coordination between monetary and fiscal policy will ensure stable headline inflation in the future.

Since the GFC, real economic slack has played a very limited role in Indonesia's headline inflation rate. The output gap contributions have declined from 2007 onwards, from a range of 4.2 to -1.7 percentage points in 2001-07 to 0.4 to -0.7 percentage points in 2008-16. This is directly related to a decline in the Phillips Curve slope (from 0.49 in 2001 to 0.03 in 2010, see Figure 12 panel b) but also to a lower volatility of the output gap. In turn, the range of Indonesian output gap simultaneously declined from a range of $4.2 \%$ to $-1.8 \%$ between 2001 08 to a range of $0.4 \%$ to $0.7 \%$ thereafter.

The quantitative importance of import price inflation has also diminished over time, especially non-oil-import price inflation. After an increase from 0.13 in 2001 to 0.31 in 2006, the coefficient of import prices stabilizes at around 0.08 from 2008-16 (see Figure 12 panel c). Contributions of non-oil-import and oil price inflation declined from an average of 2.4 and 1.5 percentage points between 2001-08 to 0.83 and 0.13 percentage points thereafter. The higher impact of oil price inflation from 2000-07 appears to be associated with pressures from administrated prices arising from energy subsidy reforms (Hendar, 2015). After 2008, however, better coordination between the central bank and the government's policy on administrated prices has helped attenuate the impact of oil price fluctuations on inflation.

\section{Malaysia}

Malaysian inflation rates have remained remarkably stable since the GFC when compared to the other ASEAN-5 countries. Over our sample, Malaysian headline inflation has averaged $2.5 \%$, out of which 2.08 percentage points are explained by forward-looking inflation expectations and only 0.2 percentage points are related to economic slack and import inflation (output gap 0.02 percentage points, non-oil-import price inflation 0.06 percentage points, oil price inflation 0.11 percentage points). A relatively high and even increasing forward-looking coefficient and stable long-run expectations (Figure 3) have decisively contributed to limit disinflationary pressures stemming from falling oil and import prices since 2014.

Since the early 2000s Bank Negara Malaysia (BNM) has steadily enhanced its monetary policy framework, transparency, and communication strategy regarding its objectives, namely low and stable inflation with sustainable growth. Since mid-2003 monetary policy statements have been released on a quarterly basis and, from 2006 onwards, shortly after Malaysia moved from a U.S. Dollar peg to effective exchange rate stability, statements are released directly after the monetary policy meetings.

Improvements in the monetary policy framework in response to the GFC seemed to strengthen the shift toward forward-looking dynamics in Malaysian inflation. The Central Bank Act in 2009 redefined and expanded not just the BNM monetary policy framework, but also further strengthened existing communication and transparency in quarterly economic and financial reports, monthly statistical publications, press conferences, statements, as well as annual 
reports, including BNM forecasts for economic growth, inflation and policy outlook. Monetary policy statements are now released immediately after the MPC meetings, which, since 2010, take place every two months instead of 8 times per year.

Figure 12: Main Inflation Components: Malaysia

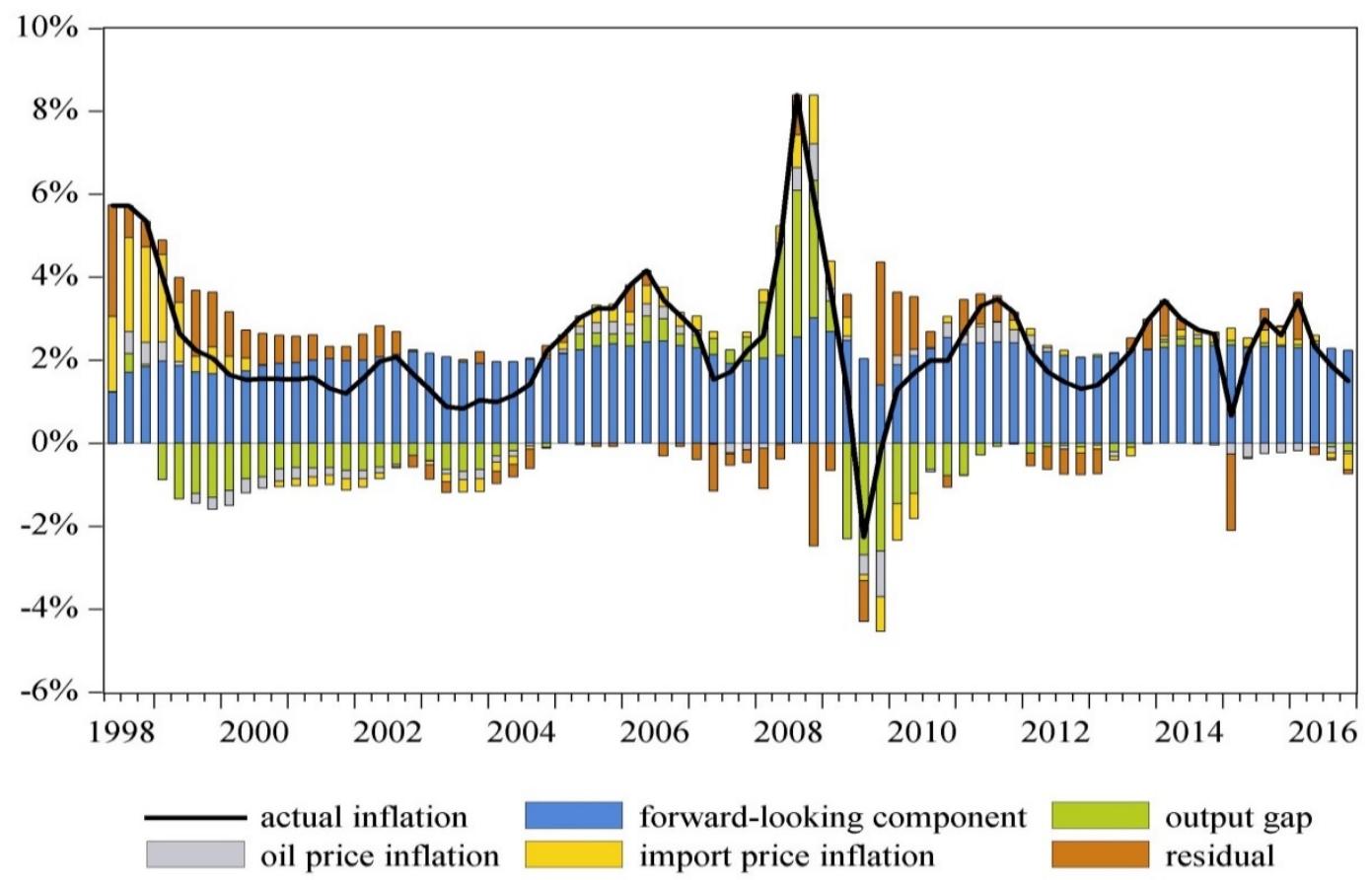

Figure 13: Time-varying Coefficient Estimates: Malaysia

(a) Trend expectation

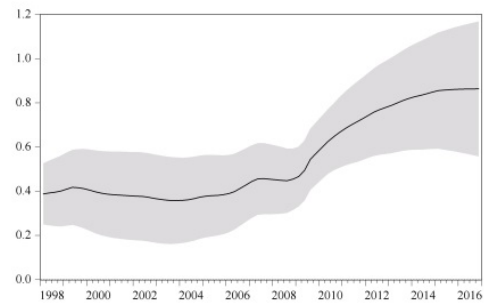

(b) Economic slack

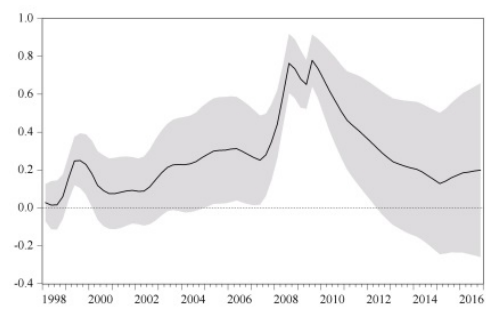

(c) Import inflation

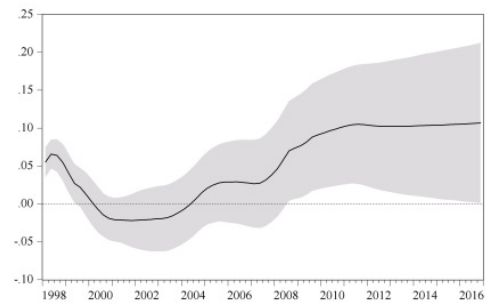

Our results suggest those efforts are reflected in inflation dynamics. The contribution of inflation expectations increased from an average of 1.8 percentage points between 2002-07 to an average of 2.3 percentage points over the period 2008-16 (see Figure 12). Trend inflation estimates are rather stable around 2.5\% throughout the entire sample (see Figure 3) and the rise in forward-looking dynamics can mainly be attributed to a rise of the forward-looking coefficient (Figure 13 panel a) doubling from 0.4 over 2002-05 to 0.8 over 2006-16. 
Overall, the quantitative importance of economic slack for inflation dynamics is relatively limited, with the exception being the GFC period. The decline in output had a large negative impact on Malaysian headline inflation during the GFC, with the contribution ranging from 3.2 to -1.6 percentage points over 2008-10. Apart from the crisis period around 2008, economic slack has a rather limited impact on inflation, thus resembling the results for the ASEAN-5 region discussed in the previous section. The altered impact of the output gap on inflation during the GFC can, in part, be explained by a rise in the coefficient of economic slack (see Figure 13 panel b). The slope parameter is roughly 0.4 across the sample, but rises to 0.8 over the 2008-10 period.

Non-oil-import and oil prices have a very limited impact on Malaysian headline inflation. As apparent from Figure 13, the contributions of import inflation to Malaysian headline inflation is rather stable but small, ranging from 0.46 to -0.24 percentage points for non-oil-import inflation and 0.37 to -0.26 percentage points for oil price inflation over the entire sample. The coefficient of import inflation in contrast depicts statistically significant time variation (see Figure 13 panel c) and increases from 0.006 over 2002-08 to 0.1 over 2009-16. The stable and limited contribution of oil price movements to inflation movements might be related to the fact that Malaysia is a crude oil exporter, whereby crude oil prices are substantially administered for most of the sample. However, the gradual liberalization of energy prices and the introduction of a Goods and Service Tax via the fiscal act in 2010 might also influence inflation in the future. ${ }^{9}$

\footnotetext{
${ }^{9}$ As pointed out by Singh (2016), the fiscal act of 2010 might alter inflation volatility due to the removal of subsidies on selected food, fuel, and utilities as well as the introduction of a goods and service tax. After the gradual removal of subsidies, Malaysia implemented a managed-float pricing mechanism for fuel in December 2014, whereby fuel prices are adjusted monthly in response to changes in market prices. This might alter the pass-through of oil price movements to headline inflation in the future, increasing inflation volatility. Further, future tax rate changes of the recently introduced goods and service tax will eventually map into consumer price developments. Indeed, the tax rises in 2015 most likely contributed to offset the declines in oil prices in 2015.
} 


\section{Philippines}

Inflation expectations have gained importance for Philippines' inflation dynamics, although long-run trend inflation has been on a steady downward trend from around 4\% between 19952008 to $2.9 \%$ in 2016, altering the risk of disinflationary pressures from import price inflation. Over the entire sample, forward-looking dynamics account for $72 \%$ of headline inflation (on average 3.6 percentage points of $4.9 \%$ headline inflation). In comparison, the contributions of economic slack and import inflation are rather limited.

Over 1996-2007, 64\% of the average headline inflation (on average 3.64 percentage points of $5.8 \%$ headline inflation) is explained by forward-looking dynamics (see Figure 1). Since the GFC, this share increased to $87 \%$ (on average 3.4 percentage points of $3.9 \%$ headline inflation over 2008-16). A possible explanation is that the decline of Philippines' headline inflation reflects the effect of decreasing trend expectations. In contrast, the weight with which trend inflation enters the inflation process has been stable, since the coefficient of the trend expectations (see Figure 15 panel a) does not deviate significantly from around 0.4 across the entire sample and, thus, cannot explain the rising importance of forward-looking component.

Inflation sensitivity to business cycle conditions has gradually increased over time. Since the onset of the GFC, the coefficient of economic slack in the Philippines increased from 0.03 in 1996 to 0.81 in 2008 (see Figure 15 panel b), pointing to a significant steepening of its Phillips Curve. The increasing sensitivity to the output gap is not translated to the contribution of economic slack. This is mainly due to reduced volatility of the output gap since the GFC. Standard deviations of the output gap decline from 1.33 over 1996-2009 to 0.74 from 2010 onwards. Over the entire sample contribution of economic slack ranges between 2.71 to -1.29 percentage points.

Non-oil-import and oil price inflation have a limited impact on headline inflation in the Philippines. The contribution of import prices to headline inflation declines substantially (see Figure 14). Over 1996-2002, an average of $28 \%$ of headline inflation is associated to non-oilimport inflation (1.7 percentage points of $6 \%$ average headline inflation), while between 200316 the relative contribution declined to $3 \%$ ( 0.1 percentage points of $4.4 \%$ average headline inflation). In contrast, oil price contributions are rather stable across the sample ranging from 1 to -0.6 percentage points. The underlying coefficient of import inflation (see Figure 15 panel c) increases from 0.1 in 1996 to 0.41 in 2006 and stabilizes around 0.23 thereafter. 
Figure 14: Main Inflation Components: Philippines

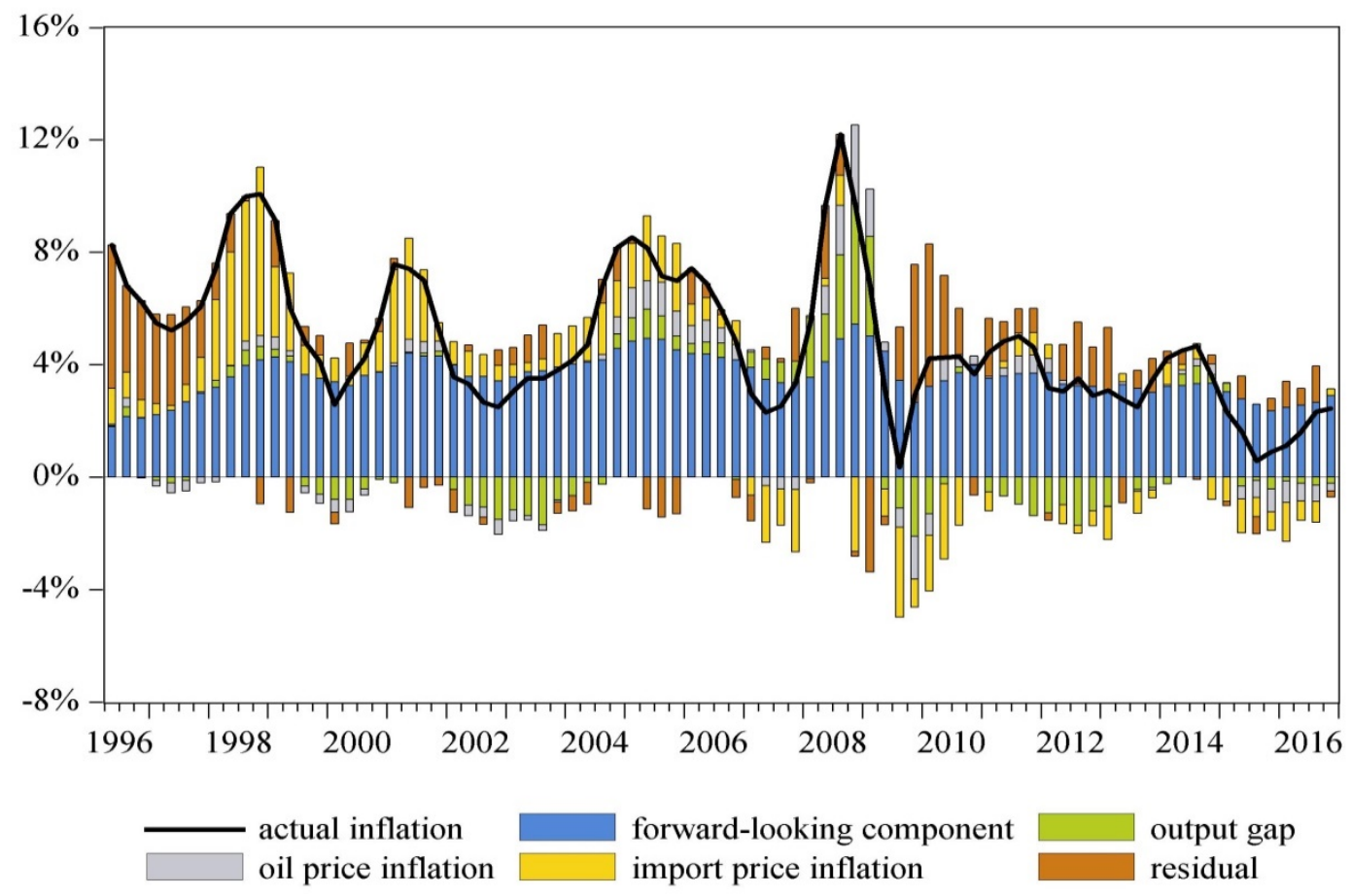

Figure 15: Time-varying Coefficient Estimates: Philippines

(a) Trend expectation

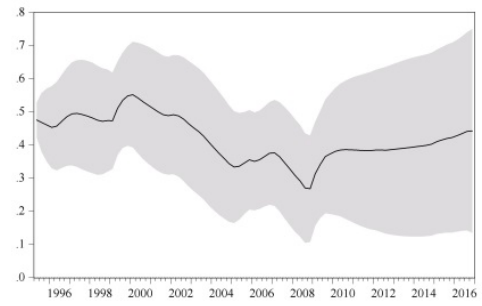

(b) Economic slack

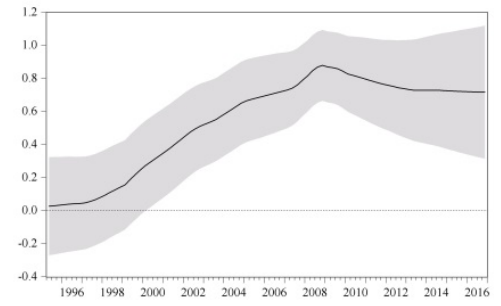

(c) Import inflation

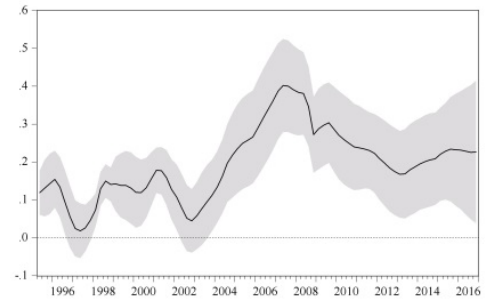

Overall Philippines' headline inflation stabilizes after the GFC, remaining within the set target range, which may help explain why forward-looking dynamics play an increasing role during this period. Guinigundo (2016) also studies inflation dynamics in the Philippines and concludes that the anchoring of inflation expectations may have strengthened. Our results suggest that the increasing contribution is not due to increasing sensitivity of inflation to forward-looking expectations but rather explained by the fact that both inflation rates and long-term inflation expectations have declined steadily. The long-run trend expectations were somewhat stable, but nonetheless below the BSP official inflation target of 3\% over 2014-16. From the perspective of monetary policy and central bank transparency, a continuation of inflation expectations below official inflation target increases the risk of inflation expectations deanchoring in the future. Against a background of expected lower oil prices, recurrent disinflation episodes may become more likely in the future. 


\section{Singapore}

Being a small and very open economy, Singapore's inflation dynamics are particularly vulnerable to cost-push shocks in times of economic turmoil. Singapore's inflation drivers exhibit significantly higher variation over time than the other large ASEAN economies. Between 1996 and 2016, headline inflation averaged 1.6\% (see Figure 16), out of which forward-looking dynamics explain 1.85 percentage points. Only $0.16,0.47$, and -0.11 percentage points of headline inflation is explained by movements of economic slack, non-oilimport and oil price inflation, respectively.

Singapore's headline inflation volatility increased after the GFC and experienced strong disinflationary pressures from 2013 up to 2016, which can be related to the fall in non-oilimport and oil price inflation. This fall in non-oil-import and oil price inflation are relatively strong, outweighing the increasing importance of forward-looking dynamics and pushing inflation rates down from 4.7\% in 2012 to 1\% in 2014, and into negative territory in 2015 and 2016.

The importance of forward-looking dynamics increased starting from the mid-2000s and has helped to mitigate large supply shock effects. The contribution of inflation expectations increases from 0.2 percentage points in 1996 to an average of 2.2 percentage points between 2007 and 2016, explaining 88\% of average headline inflation during that period. The rising importance of inflation expectations stems from an increasing coefficient (see Figure 18 panel a) of forward-looking dynamics, which rises from 0.19 in 1996 to 0.34 in 2016 (in line with the results in Meng, 2016). However, the coefficient on inflation expectation drops to 0.05 in 2008, after which it increases again to 0.39 in 2010. This sudden decline and subsequent rise of the coefficient is due to an abrupt drop of inflation expectations in 2004 from $2.2 \%$ to $1.3 \%$ (see Figure 3). Inflation expectations remained at this low level through 2009 when expectations suddenly rose to $1.9 \%$. Since we do not have long-run trend estimates and rely on inflation expectations form Consensus Economics in the Singapore case, it is likely that this sudden movement reflects common drawbacks of survey-based inflation expectations measures (see Section on forward-looking dynamics).

The importance of cyclical conditions as driver of Singapore's inflation is limited since 1998. Average contribution of economic slack is 0.51 percentage points and rather modest except for the GFC. This is also reflected in the dynamics of the coefficient on real economic activity (see Figure 17 panel b), which is 0.14 between 1996 and 2004, rises to 0.46 during the GFC and declines again to 0.05 in 2016. 
Figure 16: Main Inflation Components: Singapore

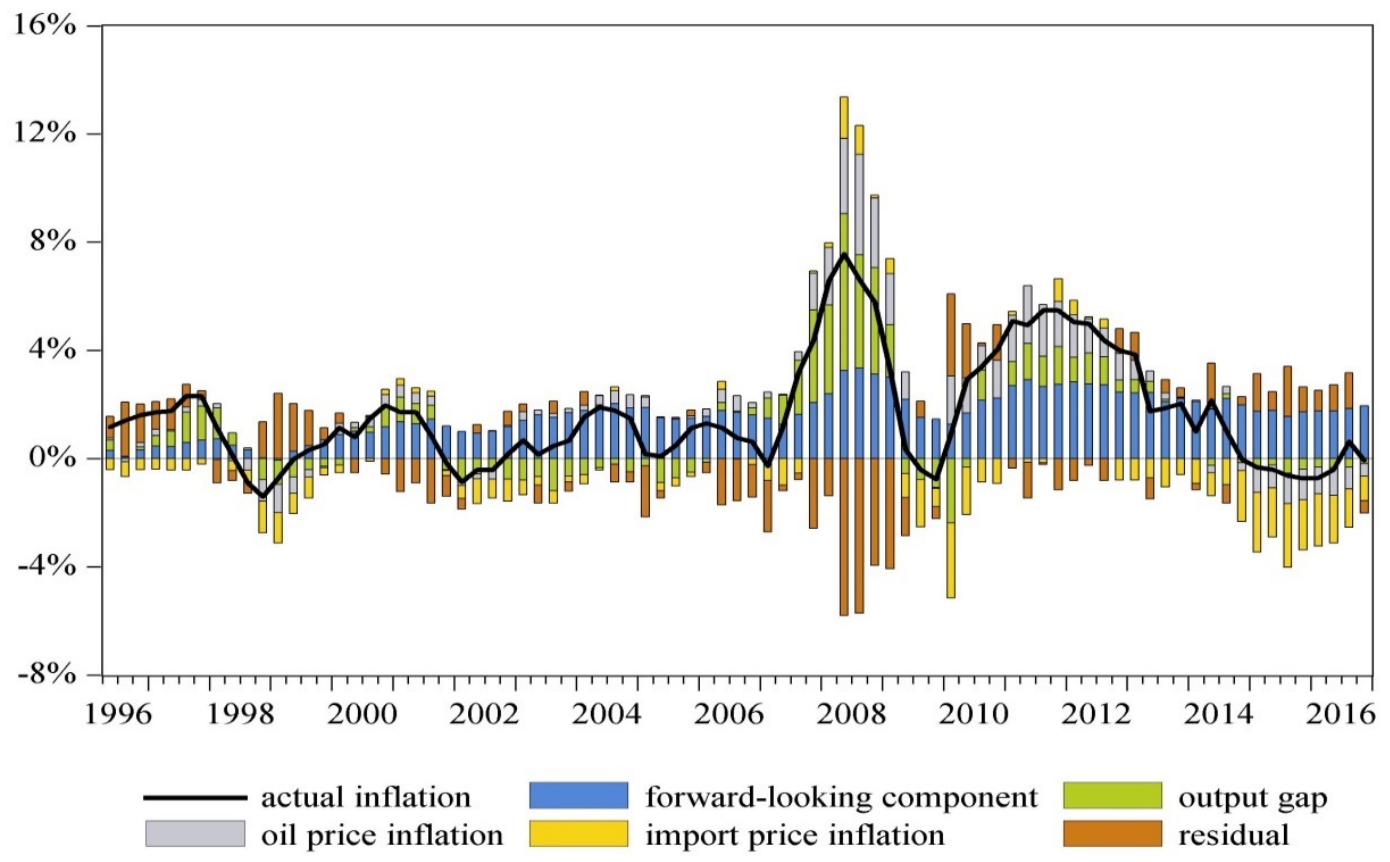

Figure 17: Time-varying Coefficient Estimates: Singapore

(a) Trend expectations

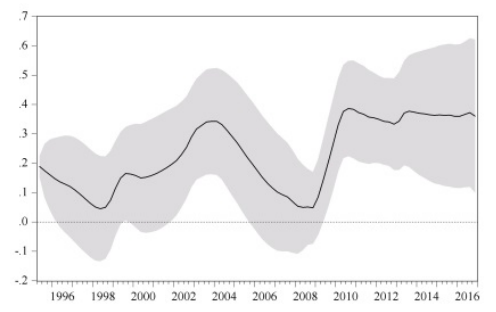

(b) Economic slack

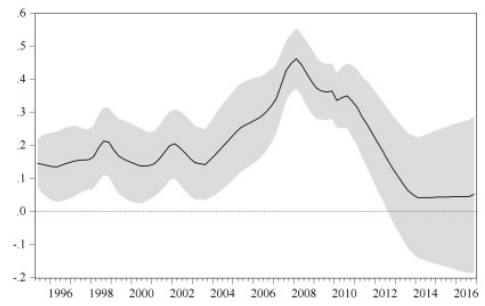

(c) Import inflation

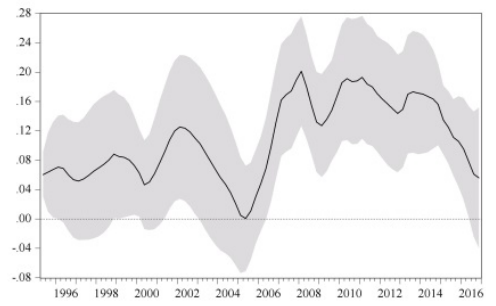

Non-oil-import and oil price inflation is more important for Singapore's headline inflation compared to other ASEAN-5 countries and increases over time. Singapore has a trade intensive economy and this is reflected in a larger relative contribution of non-oil-import and oil price inflation to headline inflation compared to the ASEAN-5 region. The average contribution of non-oil-import and oil price inflation increased from 0.59 percentage points between 1996 and 2006 to 1.9 percentage points from 2007 onwards, whereby contributions of non-oil-imports price inflation are systematically higher than those of oil price inflation. In line with the rise of contribution to headline inflation the coefficient of import inflation increases from 0.06 in 1996 to 0.15 in 2014, but reveals a decreasing trend thereafter. The steady decline in property prices in recent years may also be another disinflationary factor, as possibly reflected in the negative residual towards the end of the sample. 


\section{Thailand}

Although the forward-looking component of Thai headline inflation substantially strengthened following the AFC, it was not able to offset recent disinflationary pressures stemming from oil price declines. The evolution of Thailand's monetary policy framework after the AFC helped anchor inflation expectations and strengthen forward-looking dynamics in inflation until the GFC. However, Thailand experienced deflation in 2008 due to a persistently negative output gap and in 2015 due to an increased pass-through of a decline in oil prices from 2014 onwards. During these episodes, the expectation-driven component of Thai headline inflation was not able to offset supply-side shocks, pointing toward further scope for improvement in monetary policy communication.

Thai headline inflation has been on a gradual downward trend since 1998. Thailand's headline inflation declined substantially from an average of $6.5 \%$ before the AFC to $2.5 \%$ thereafter. Since 2001, Thailand has adopted an explicit inflation targeting scheme and the implementation of a well-defined monetary policy framework has an important impact on Thailand's inflation dynamics.

After the AFC, forward-looking dynamics explains more than half (53\%) of headline inflation, two-thirds more than before the AFC (33\%). However, disinflation pressures after the GFC and finally deflation since early 2015 raised concerns about the weakening of that expectations channel. From 2001 to 2010, the absolute contribution of forward-looking dynamics is 2.4 percentage points but decreases to 2 percentage points thereafter. Importantly, the lower contribution of forward-looking dynamics reflects both lower coefficient estimates (see Figure 19 panel a) and a decline of long-run trend inflation (see Figure 2).

Contributions of economic slack to Thailand's headline inflation show a similar nonlinear pattern compared to the rest of the ASEAN-5 countries: The contribution of economic slack is rather limited in "normal times," but peaks during the AFC and GFC. Time-varying contribution of economic slack to Thailand's headline inflation is comparable to the rest of the ASEAN-5 countries. The impact of output gap fluctuations reflects a nonlinear pattern in the sense that the contribution is rather limited but gains importance during the GFC. As shown in Figure 19, the contribution of economic slack to inflation is on average -2.13 and -2.58 percentage points during the AFC and GFC, respectively. In contrast, since 2010 the average contribution is -0.08 percentage points. The increased importance of the output gap during the GFC is not only due to a higher volatility of economic slack but also to a temporary increase of structural relevance in the inflation process. The coefficient of economic slack increases from 0.03 in 1995 to 0.54 in 2008 and thereafter declines to 0.3 in 2015 (Figure 19 panel b). 
Figure 18: Main Inflation Components: Thailand

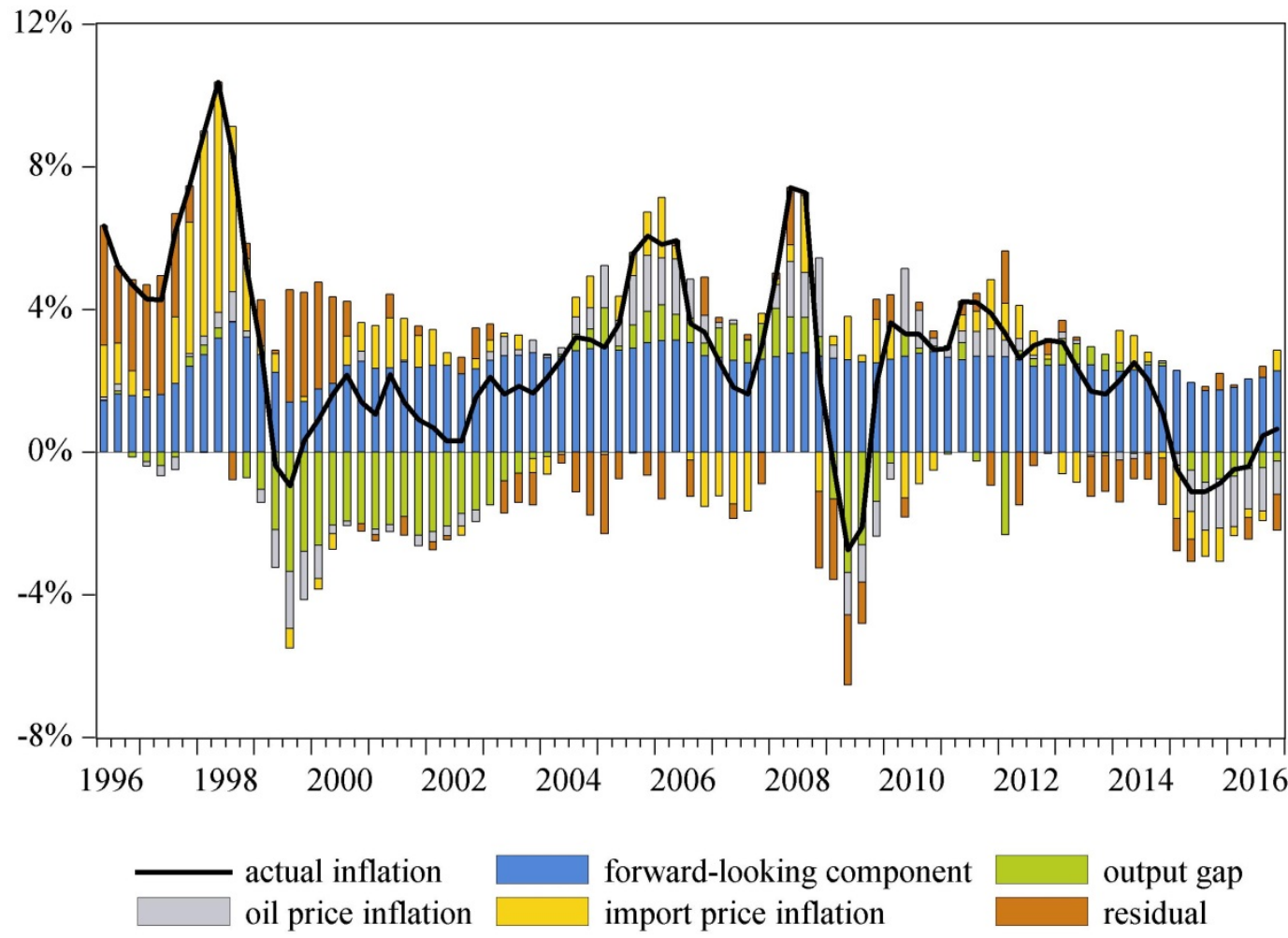

Figure 19: Time-varying Coefficient Estimates: Thailand

(a) Trend expectations

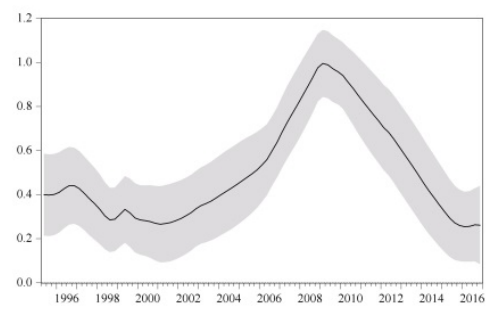

(b) Economic slack

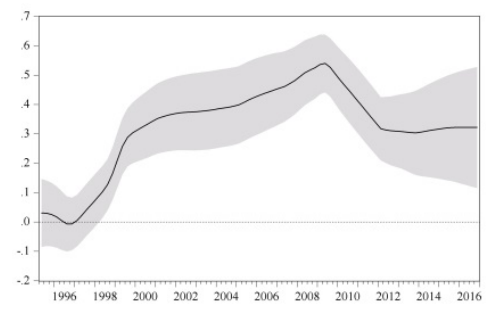

(c) Import inflation

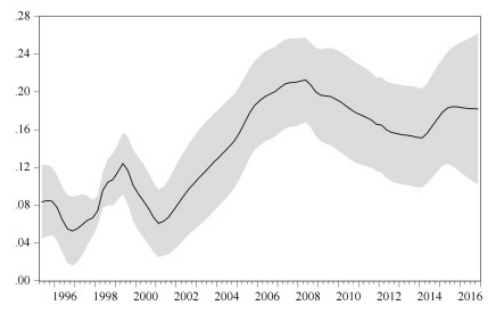

Contributions of oil and non-oil-import price inflation are rather stable over-time and do not solely explain recent disinflation pressures. Being a strong oil importer, it is natural that oil price movements should have an important effect on Thai headline inflation. In the episode of disinflation (and temporary deflation), the oil price pass-through to consumer prices appeared to be particularly strong. However, Figure 18 reveals that the contribution of oil price movements to headline inflation was rather constant, which may reflect Thai government's efforts to stabilize domestic oil prices by means of an oil fund levy and fuel excise (see Direkudomsak, 2016). For the entire sample, the absolute contributions of non-oil-import and oil price inflation average 0.54 and 0.75 percentage points, respectively. Thereby, the contribution of non-oil-import inflation declines from an average of 1.44 percentage points during the AFC to 0.47 percentage points for the remaining sample. The coefficient of import 
inflation increases from 0.08 in 1996 to 0.2 in 2008 and remains stable thereafter. The unchanged quantitative impact of import inflation on headline inflation is a combined effect of lower non-oil-import price volatility and altered sensitivity to import price inflation.

The evolution of the key drivers of Thailand's inflation dynamics since 1998 has important implications for monetary policy. Thailand is the only country among the ASEAN-5 countries that experienced deflation during the GFC. In fact, while Thailand's headline inflation dynamics became increasingly forward-looking after the AFC, since the GFC the weakening of the expectation component has made Thailand's inflation more vulnerable to adverse price shocks.

Thailand's well developed monetary policy framework contributed to anchor inflation expectations before the GFC. Since 2000 onwards, the Bank of Thailand (BOT) has operated under an inflation targeting regime, maintaining low inflation rates and stabilizing the exchange rate. ${ }^{10}$ The BOT has continuously developed its monetary policy framework as well as transparency and communication strategy. ${ }^{11}$ In particular, the change from core (target of $0.5 \%-3 \%$ for quarterly average core inflation) to headline inflation target (annual average of $2.5 \% \pm 1.5 \%$ ) in early 2015 coincided with the intensification of the disinflationary pressures stemming from the decline in oil prices and represented an important challenge for the central bank's communication. The Memorandum of Understanding with the Minister of Finance specifies that the Monetary Policy Committee (MPC) should explain the reasons for missing the inflation target every year. Moreover, in addition to its regular communication and official publications on the state of the economy and monetary policy decisions, the BOT must issue a letter detailing the period within which inflation is expected to return to the target band and how the Committee contemplates the appropriate monetary policy response. Unfortunately, BOT's assessment of headline inflation returning to target did not materialize in 2015 and 2016. ${ }^{12}$

Our results suggest that the reduced importance of the forward-looking component could not offset the oil price shock that pushed Thailand into deflation. The development of monetary policy framework, communication strategy, and expectations management strengthened the forward-looking component of Thailand's headline inflation until the GFC. However, disinflationary pressures and deflation in recent years do not solely hinge on falling oil prices, but on the increase in inflation persistence, Continuous communication and policy actions to manage expectations and better align them to the inflation target can help counteract adverse

\footnotetext{
10 Since the 1995, the monetary policy framework of the Bank of Thailand (BOT) can be categorized into three different regimes. From 1995 to 1997 the BOT followed a pegged exchange rate regime to the US Dollar, from 1997 to 2000 the BOTs monetary policy framework comprised monetary targeting, and from 2000 to 2018 it is inflation targeting..

${ }^{11}$ The latter, a Monetary Policy Report, the publication of decisions of Monetary Board meetings, speeches by BOT officials, as well as the economic forecasting models and a monetary policy outlook.

${ }^{12}$ In February 2015, the Thai MPC attributed negative inflation to the sharp decline in oil prices. While noting potential downside risks to its forecasts, the MPC expected inflation to return into positive territory in 2015 Q3, benefitting from lower oil prices raising disposable income and still high inflation expectations. No policy stimulus was envisaged at that stage, but policy rates were cut twice to $1.5 \%$ by April 2015. Throughout 2015, however, inflation remained in negative territory, driven by persistent declines in energy prices, fresh food prices and low demand pressures. By January 2016, the return to positive territory was expected within the first half of 2016, to the target band in the second half of 2016, and to the mid-point target within two years. Monetary policy has remained on hold since April 2015 and attention to adverse consequences of excessively aggressive policy actions on financial market volatility and financial stability risks was stressed.
} 
cost-push shocks, like the oil price fall in 2014 and 2015. Among others, ${ }^{13}$ Chantanahom et al (2004) find that well anchored inflation expectations had been instrumental to prevent secondround effects from excessive swings in commodity prices in Thailand.

The downward trend in long-term inflation expectations in Thailand since 2015 may become a risk for future inflation (see Figures 3 and 4). BOT's communication is crucial to manage inflation expectations and dismiss the perception of constrained monetary policy. Further guidance in terms of envisaged actions to achieve the target over a given time horizon is fundamental to avoid a de-anchoring of long-term inflation expectations after quite a protracted period of below-target inflation. A critical assessment of past performance, a detailed discussion of the shocks impairing the achievement of the inflation target and a further elaboration on the internal debate underlying the policy decisions - reflecting dissenting views and arguments in the MPC minutes if applicable - can be instrumental to guide private sector's expectations and enhanced the effectiveness of monetary policy. In addition, the announcement of an inflation target over a longer horizon than one year may also contribute to the stronger anchoring of inflation expectations.

\section{ROBUSTNESS CHECKS}

This section reports a series of sensitivity analyses on our benchmark model, equation (1). We assess the performance of our estimation on two key dimensions, namely data choices of distinct measures and model specifications. Our qualitative findings are robust to all these sensitivity checks. ${ }^{14}$

\section{A. Different Measures of Macroeconomic Indicators}

Turning to the specific model variations and re-estimations, the first set of robustness check is concerned with different measures of macroeconomic indicators used in the benchmark estimation.

\section{Measures of the Output Gap}

The first variation is related to possible differences in the measurements of the output gap due to different filtering techniques. In our benchmark model specification, we use the standard HP-filter. As a robustness test, we obtain output gap measures from a two-sided band-pass filter, which also limits the sample size compared to the benchmark model. Differences between the results from the re-estimated benchmark model with band-pass filtered output gap and HP-filtered output gap are quantitatively marginal and, therefore, omitted. Qualitatively the results of coefficients and contributions are also very similar. Quantitative differences appear in the coefficients of output gap that are slightly higher during the GFC across countries.

\footnotetext{
${ }^{13}$ Manopimoke and Direkudomsak (2015), Khemangkorn et al (2008), and Carney (2015).

${ }^{14}$ Detailed results are shown in the Appendix, which is available upon request from the authors.
} 
Further, the median contribution of time-variation of output gap and import price inflation is marginally lower. ${ }^{15}$

\section{Indicators of Inflation Expectations}

The second variation is concerned with possible differences between the estimates of the longterm inflation trend-expectations and more traditional survey-based expectations. Since survey-based expectations might be systematically biased, we use long-run trend expectations estimates, incorporating information from survey-based expectations. Our results show that inflation expectations are a crucial driver for inflation dynamics that can potentially outweigh exogenous cost-push shocks. Therefore, it is important to verify whether coefficients and contributions are robust across different measures of inflation expectations. Re-estimating our benchmark model using long-run inflation expectations from Consensus Economics yields qualitatively similar results in terms of variable contributions to inflation dynamics. As seen in Figures 3 and 4, trend expectations and expectations from Consensus Economics show some quantitative differences depending on the point in time and the respective country. Overall, survey expectations are systematically higher than the long-run inflation trend estimates. This is also reflected in the median contributions of forward-looking component using survey expectations compared to the benchmark results. The median contributions related to the timevariation in parameters are quantitatively slightly larger for the output gap and import price inflation and less pronounced for the forward-looking component. Estimated coefficients, however, show little differences compared to the benchmark results. ${ }^{16}$

\section{Import Price Measures}

Import price inflation data might depend on whether it is retrieved from terms of trade or obtained from national accounting. Although data quality and provision are consistently improving, depending on the country there are still substantial differences across import price series retrieved from different sources. Thus, we also re-estimate our benchmark model with import prices obtained from the WEO database as a third variation. Overall, qualitative implications of the re-estimated coefficients and contributions are in line with our benchmark model estimates and respective contributions. Although the combined contribution of oil and import price inflation is quantitatively very similar to the benchmark results, the weight between the contribution of import and oil price inflation shifted toward the latter.

\section{B. Model Specifications}

The second set of robustness checks is concerned with the model specification.

\footnotetext{
${ }^{15}$ We also investigate one-sided and two-sided HP filtering over different end-points. The impact is generally quantitatively small and does not affect our qualitative findings. Output gap estimates can also be obtained using multivariate filters, which add some economic structure to the estimates of potential output by conditioning them on some basic relationships based on economic theory (e.g. a Phillips curve). While multivariate filters may therefore provide estimates that are more consistent with theory, they may also entail the cost of model mispecification (see Alichi and others, 2015, for a comparison of results).

${ }^{16}$ Estimation results for Singapore are exclusively based on long-term Consensus Forecasts as the estimation of trend inflation was subject to unusual uncertainty.
} 


\section{Impact of Time-varying Parameters}

A crucial element of the analysis is the estimation of the Phillips Curve allowing for timevarying parameters to capture potential changes in inflation dynamics over time. As quantitative illustration of their importance, Figure 20 below shows the differences, as the median across countries, in the contributions to inflation from constant parameters with respect to that from our benchmark time-varying parameter specification. ${ }^{17}$

Figure 20: Differences in Contributions to Inflation: Constant vs Time-varying Parameters

(a) Forward-looking dynamics

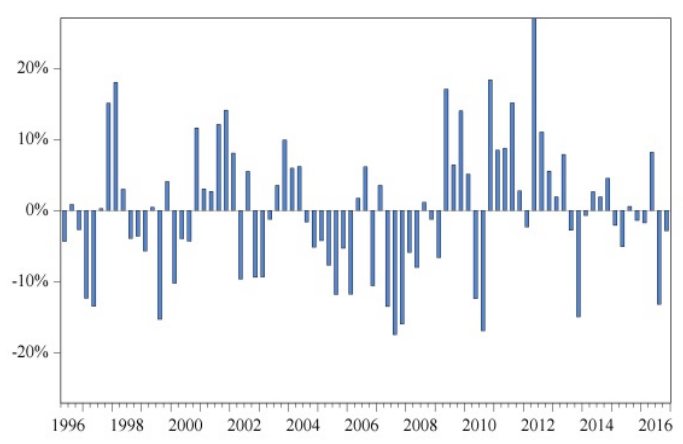

(c) Non-oil-import price inflation

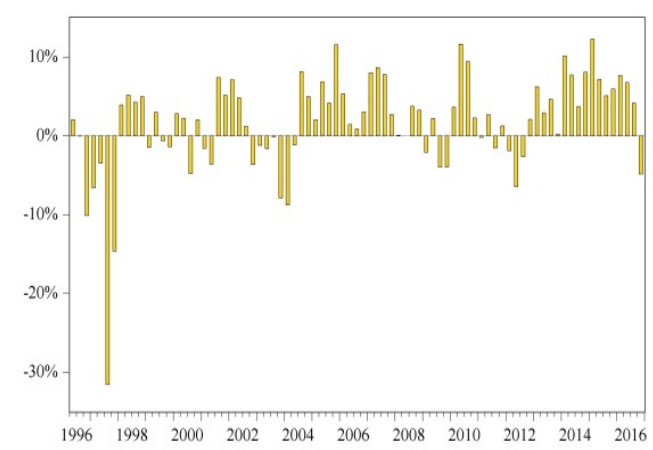

(b) Economic slack (output gap)

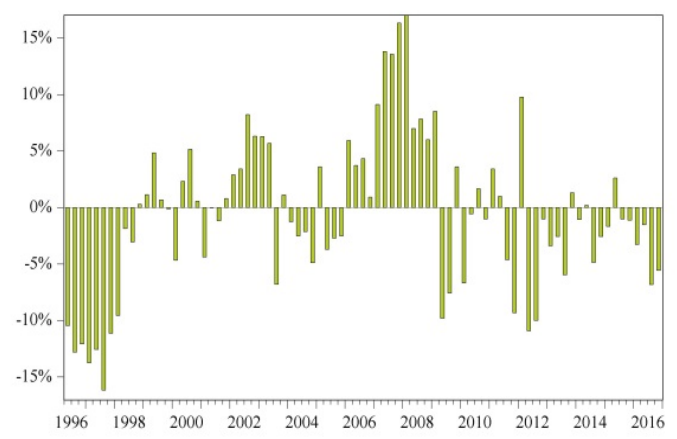

(d) Oil price inflation

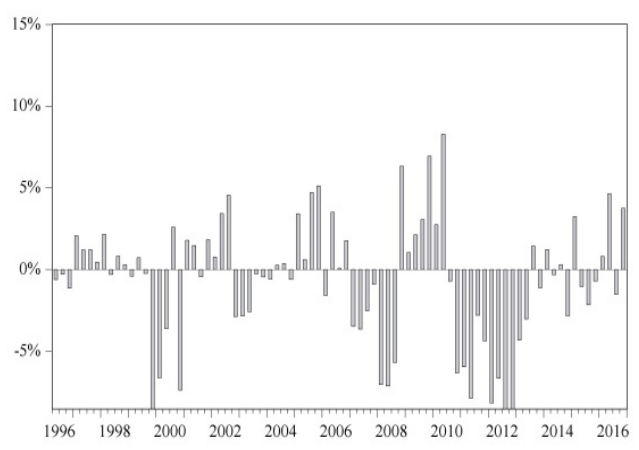

For the contribution of forward-looking dynamics (see Figure 2 panel a), a constant parameter estimation would imply ignoring a significant amount of variation in inflation overall, alternating periods of broad underestimation (e.g. 2004-08), with overestimation (2009-13), and again mild underestimation (2015-16).

The time-variation of the slope parameter becomes most relevant during recessionary episodes. However, panel b evidence suggests that constant parameters may both underestimate the impact (as during the AFC) or overestimate it (as during the GFC). The contribution from nonoil-import inflation instead tends to be generally overestimated under constant parameters (see Panel c), while the evidence is not so clear for those from oil price inflation, with persistent

\footnotetext{
${ }^{17}$ This illustration compares the median contributions across ASEAN-5 countries between the two model specifications.
} 
episodes of overestimation alternating with other of overestimation (particularly over 2010-13, Panel d).

\section{Coefficients of Non-Oil-Import Price and Oil Price Inflation}

We also investigate possible differences of coefficients of non-oil-import price inflation and oil price inflation in the Phillips Curve. As mentioned in the estimation section, in our benchmark model we only estimate three parameters; a coefficient for the forward-looking dynamics, a coefficient for the economic slack (the Phillips Curve slope), and a coefficient for overall import price inflation, averaging across different dynamics of non-oil-import prices and oil prices. We decompose the contributions using the import price coefficient for both series ex-post. The reasoning for our benchmark procedures is that import price inflation should, in principle, contain oil price inflation for oil importing countries. But since not all ASEAN-5 countries are oil importers, in an alternative specification we explicitly include non-oil-import price inflation and oil price inflation in the model, estimating four parameters.

Results from the model with four parameters depict much higher contributions of the residuals to median and to country-specific headline inflation, whereby median contributions account for around $30 \%$, as compared to roughly $10 \%$ in the benchmark estimation. Moreover, the contribution of oil price inflation is substantially altered, whereby the contributions of forwardlooking dynamics are quantitatively lower as compared to benchmark results. The countryspecific coefficients of non-oil-imports are systematically higher by roughly 0.05 , but reveal the same dynamics as in the benchmark case. For the oil-exporting countries (Indonesia and Malaysia) the coefficients of oil price inflation are significantly positive throughout the sample, but reveal little time variation. The oil price inflation coefficients are small and do not change significantly over time across countries. The significant levels of coefficients range from 0.005 to 0.028 across countries and time. The remaining coefficients are negligibly different quantitatively. Overall, the fourth specification reveals qualitatively similar result of the benchmark estimation.

\section{Models including oil price inflation and exchange rate}

As most ASEAN-5 economies are highly open economies, exchange rate movements might have a relevant pass-through to headline inflation. When we augment the model specification with the exchange rate, ${ }^{18}$ in addition to expectations, economic slack, and oil price inflation, we find evidence of limited pass-through for the ASEAN-5 countries, in line with Devereux and Yetman (2014). The coefficient on exchange rates is not significant across countries and time. ${ }^{19}$ The median contributions of the forward-looking component only reveals slight quantitative differences compared to the benchmark model. The median and country-specific contributions of the exchange rate are quantitatively very small. In turn the median and country-specific contributions of oil price inflation are larger as in the benchmark model.

\footnotetext{
${ }^{18}$ We take the nominal exchange rates (local currency to US Dollar) from Haver.

${ }^{19}$ Singapore is an exception with a significant coefficient of -0.8 . The coefficient does not change significantly over time.
} 


\section{Conclusions}

This paper provides quantitative evidence on the evolution of consumer price inflation dynamics in ASEAN-5 economies since the AFC. We focus on four key inflation drivers -inflation expectations, economic slack, non-oil-import, and oil price inflation- and assess how the role of each has evolved since 1996. To that end, we estimate Phillips Curves for each country allowing for time-varying parameters.

We find a strong role for monetary policy frameworks in shaping inflation dynamics in the ASEAN-5 countries. Inflation is increasingly forward-looking (less persistent), with the contributions of inflation expectations becoming the most important component of inflation in all countries. Specifically, our results show that inflation expectations have gradually become better anchored and that both the forward-looking coefficient (lower inflation persistence) and the overall contribution of inflation expectations display a positive relation with the evolution of ASEAN-5 central banks' transparency as measured by Dincer and Eichengreen (2014). In contrast, the quantitative impact of cyclical fluctuations has gradually diminished over time. Indeed, our results point to a significant flattening of the Phillips Curve in ASEAN economies since the GFC. At the same time, increased exchange rate flexibility and further economic integration may have reduced the effect of non-oil and oil import inflation on headline inflation.

This paper focuses on the experience of the ASEAN-5 countries in the gradual improvement of their monetary policy frameworks and how that contributes to shape inflation dynamics along with the increased integration of their economies into the global economy. We also provide a more detailed analysis of the individual country experiences that may serve as useful reference for many other emerging economies. Indeed, although our findings suggest that the improvement of monetary policy frameworks has contributed to make ASEAN-5 countries more resilient to price shocks than in the past, challenges remain. The strong disinflation and in some case outright deflation in oil-importing economies over 2014-16 indicate that supplyside shocks have not been completely offset by the forward-looking component of the inflation process. Moreover, our country-specific analysis also suggests that the protracted period of low inflation in Thailand following adverse price shocks partly reflects a weakening of the forward-looking dynamics and of the anchoring of long-term inflation expectations. In addition, the flattening of the Phillips Curve in ASEAN-5 economies unveiled here helps explain the relatively low inflation experienced across ASEAN-5 economies in 2017 despite

the significant acceleration of economic activity in all the countries in the region and worldwide. 


\section{REFERENCES}

Alichi, A., Bizimana. O, Domit, S., Fernandez Corugedo, E., Laxton, D., Tanyeri, K., Wang, H., and Zhang, F. (2015), Multivariate filter estimation of potential output for the Euro Area and the United States, IMF Working Paper 15/253.

Rahul, A., Cheng, k., Rehman, s. and Zhang, l. (2014), Potential growth in emerging Asia, IMF Working Paper 14/2.

Atkeson, A. and Ohanian, L. (2001), Are Phillips Curves seful for forecasting inflation?, Federal Reserve Bank of Minneapolis. Quarterly Review-Federal Reserve Bank of Minneapolis 25(1): 2.

Balcilar, M., Gupta, R. and Kotzé, K. (2015), Forecasting macroeconomic data for an emerging market with a nonlinear DSGE model, Economic Modelling 44: 215-228.

Benati, L. (2008), Investigating inflation persistence across monetary regimes, The Quarterly Journal of Economics 123(3): 1005-1060.

Blanchard, O., Cerutti, E. and Summers, L. (2015), Inflation and activity-two explorations and their monetary policy implications, Discussion paper, National Bureau of Economic Research.

Blanchard, O. (2016), The Phillips Curve: Back to the '60s?, American Economic Review: Papers \& Proceedings, 106(5): 31-34

Ball, L., and S. Mazumder (2011), Inflation Dynamics and the Great Recession, Brookings Papers on Economic Acticity (Spring), 337-402

Blinder, A. S., Ehrmann, M., Fratzscher, M., Haan, J. D. and Jansen, D. (2008), Central bank communication and monetary policy: A survey of theory and evidence, Journal of Economic Literature 46(4): 910-945.

Calvo, G. (1983), Staggered prices in a utility-maximizing framework, Journal of Monetary Economics 12(3): 383-398.

Carney, M. (2015). Inflation in a globalized world, speech at the Economic Policy Symposium, Federal Reserve Bank of Kansas City, Jackson Hole, Wyoming.

Chan, J., Clark, T. and Koop, G. (2018), A new model of inflation, trend inflation, and long-run inflation expectations, Journal of Money, Credit and Banking 50(1): 5-53.

Chantanahom, P., Poonpatpibul, C. and Vongsinsirikul, P. (2004), Exploring Inflation in Thailand: Through Sectoral Price Setting Behavior and Underlying Trend, Bank of Thailand. 
Coibion, O. and Gorodnichenko, Y. (2015), Information rigidity and the expectations formation process: A simple framework and new facts, The American Economic Review 105(8): 2644-2678.

Dany-Knedlik, G. and Holtemöller, O. (2017), Inflation dynamics during the financial crisis in Europe: Cross-sectional identification of long-run inflation expectations, IWH Discussion Papers, No. 10/2017.

Devereux, M. and Yetman, J. (2014), Globalisation, pass-through and the optimal policy response to exchange rates, Journal of International Money and Finance 49: 104-128.

Dincer, N. and Eichengreen, B. (2014), Central bank transparency and independence: Updates and new measures, International Journal of Central Banking 10(1): 189-259.

Direkudomsak, W. (2016), Inflation dynamics and inflation expectations in Thailand, BIS Papers No 89: 349-360.

Fuhrer, J. and Moore, G. (1995), Inflation persistence, The Quarterly Journal of Economics 110(1): 127-159.

Gali, J. and Gertler, M. (1999). Inflation dynamics: A structural econometric analysis, Journal of monetary Economics 44(2): 195-222.

Garcia, J. A. and Poon, A. (2018), What can trend inflation estimates tell about inflation in Asia?, IMF Working Paper series, forthcoming

Gerlach, S. and Tillmann, P. (2012), Inflation targeting and inflation persistence in Asia pacific, Journal of Asian Economics 23(4): 360-373.

Guinigundo, C. (2016), The role of expectations in inflation dynamics in the Philippines-has it changed following the global financial crisis?, BIS Papers No 89: 291-302.

Hendar (2016), Inflation mechanisms, expectations and monetary policy in Indonesia, BIS Papers No 89: 193-203.

Holtemöller, O. and Mallick, S. (2016), Global food prices and monetary policy in an emerging market economy: The case of India, Journal of Asian Economics 46: 56-70.

International Monetary Fund (2010), Indonesia: 2010 Article IV consultation-staff report, Technical report, International Monetary Fund. Asia and Pacific Dept, IMF Country Report No. 10/284.

International Monetary Fund (2012), Indonesia: 2012 Article IV consultation-staff report; Technical report, International Monetary Fund. Asia and Pacific Dept, IMF Country Report No.12/277. 
International Monetary Fund (2016), ASEAN-5 cluster report: Evolution of monetary policy frameworks, Technical Report, International Monetary Fund. Asia and Pacific Dep., Country Report No. 16/176.

International Monetary Fund (2018a), The ASEAN way: Sustaining growth and stability in the next 50 years, Ana Corbacho and Jay Peiris Eds., Asia and Pacific Department, International Monetary Fund.

International Monetary Fund (2018b), Regional economic outlook, Asia and Pacific Department, May.

Khemangkorn, V., Mallikamas, R. P. and Sutthasri, P. (2008), Inflation dynamics and implications on monetary policy, Discussion paper, Economic Research Department, Bank of Thailand.

Mandalinci, Z. (2015), Forecasting inflation in emerging markets: An evaluation of alternative models, Discussion paper, CReMFi, School of Economics and Finance, QMUL.

Manopimoke, P. (2015), Globalization and international inflation dynamics: The role of the global output gap, Discussion paper, Puey Ungphakorn Institute for Economic Research.

Meng, K. C. (2016), The inflation process and expectations in Singapore, BIS Papers No 89: 335-343.

Mertens, E. and Nason, J. (2015), Inflation and professional forecast dynamics: An evaluation of stickiness, persistence, and volatility, Discussion paper, Centre for Applied Macroeconomic Analysis, Crawford School of Public Policy, The Australian National University.

Morgan, P. (2013), Monetary policy frameworks in Asia: Experience, lessons, and issues. Asian Development Bank Working Paper No.435.

Singh, S. (2016), Economic changes, inflation dynamics and policy responses: the Malaysian experience, BIS Papers No 89: 335-343.

Van der Cruijsen, C. and Demertzis, M. (2007), The impact of central bank transparency on inflation expectations, European Journal of Political Economy 23(1): 51-66.

Watson, M. W. (2014), Inflation persistence, the NAIRU, and the Great Recession, The American Economic Review 104(5): 31-36. 